\title{
Examination of the Potential for Formation of Energetic Compounds in Dry Sludge
}

by

M. J. Barnes

Westinghouse Savannah River Company

Savannah River Site

Aiken, South Carolina 29808

L. O. Dworjanyn

R. F. Swingle

S. D. Fink

F. F. Fondeur

M. W. Geeting

M. S. Hay

DOE Contract No. DE-AC09-96SR18500

This paper was prepared in connection with work done under the above contract number with the U.S.

Department of Energy. By acceptance of this paper, the publisher and/or recipient acknowledges the U.S. Government's right to retain a nonexclusive, royalty-free license in and to any copyright covering this paper, along with the right to reproduce and to authorize others to reproduce all or part of the copyrighted paper. 


\section{DISCLAIMER}

This report was prepared as an account of work sponsored by an agency of the United States Government. Neither the United States Government nor any agency thereof, nor any of their employees, makes any warranty, express or implied, or assumes any legal liability or responsibility for the accuracy, completeness, or usefulness of any information, apparatus, product, or process disclosed, or represents that its use would not infringe privately owned rights. Reference herein to any specific commercial product, process, or service by trade name, trademark, manufacturer, or otherwise does not necessarily constitute or imply its endorsement, recommendation, or favoring by the United States Government or any agency thereof. The views and opinions of authors expressed herein do.not necessarily state or reflect those of the United States Government or any agency thereof.

This report has been reproduced directly from the best available copy.

Available to DOE and DOE contractors from the Office of Scientific and Technical Information, P. O. Box 62, Oak Ridge, IN 37831; prices available from (423) 576-8401.

Available to the public from the National Technical Information Service, U. S. Department of Commerce, 5285.Port Royal Road, Springfield, VA 22161. 


\section{DISCLAIMER}

Portions of this document may be illegible in electronic image products. Images are produced from the best available original document. 
KEYWORD: Tank Farm, Dry

Sludge, Energetic

Compounds

Retention Period: Permanent

Examination of the Potential for Formation of Energetic Compounds in Dry Sludge

\author{
M. J. Barnes \\ L. O. Dworjanyn \\ S. D. Fink \\ F. F. Fondeur \\ M. W. Geeting \\ M. S. Hay \\ R. F. Swingle \\ W. R. Wilmarth
}

Publication Date: November 2, 1998

Westinghouse

Savannah River Company

Alken, SC 29808

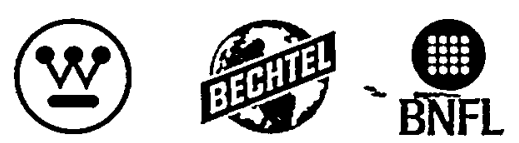


WSRC-TR-98-00407

Page 2 of 2831 off

November 2, 1998

\section{Examination of the Potential for Formation of Energetic Compounds in Dry Sludge}

AUTHORS

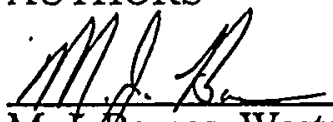

M. J. Barnes, Waste Processing Technology
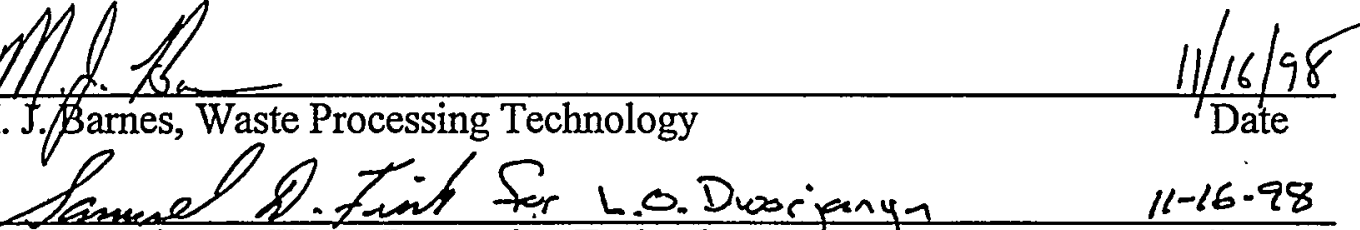

L. D. Dworjany

L. O. Dworjanyn, Waste Processing Technology

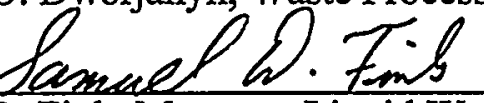

S. D. Fink, Manager, Liquid Waste Processing Technology

Date
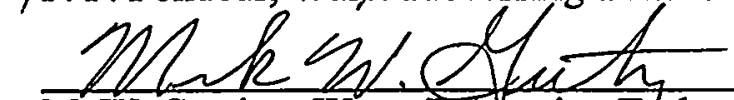

M. W. Geeting, Waste Pobdessing Technology

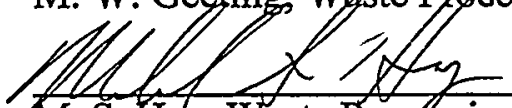

M. S. Hay, Waste Processing Technology $11-16-98$

\section{Date}

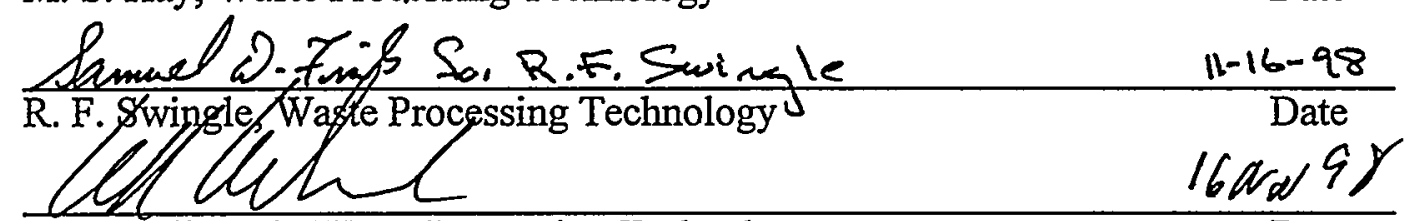

W. R. Wilmarth, Waste Processing Technology

Date

\section{DESIGN CHECK}

$\frac{\text { Samucl D. Ford for D.T. Hobls per message of } 11 / 13 / 98}{11-16-98}$ : (per Manual E7, Procedure 2.40)

APPROVALS/REVIEXW

$B 211-19-98$

B. L. Lewis, Manager, CST Engineering Support

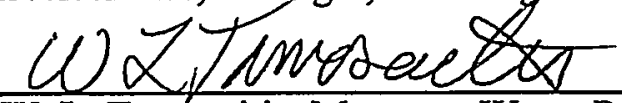

W. L. Tamosaitis, Manager, Waste Processing Technology

Date

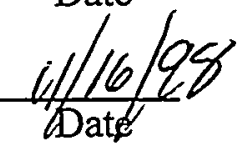


WSRC-TR-98-00407

Page 3 of 31

November 2, 1998

\section{TABLE OF CONTENTS}

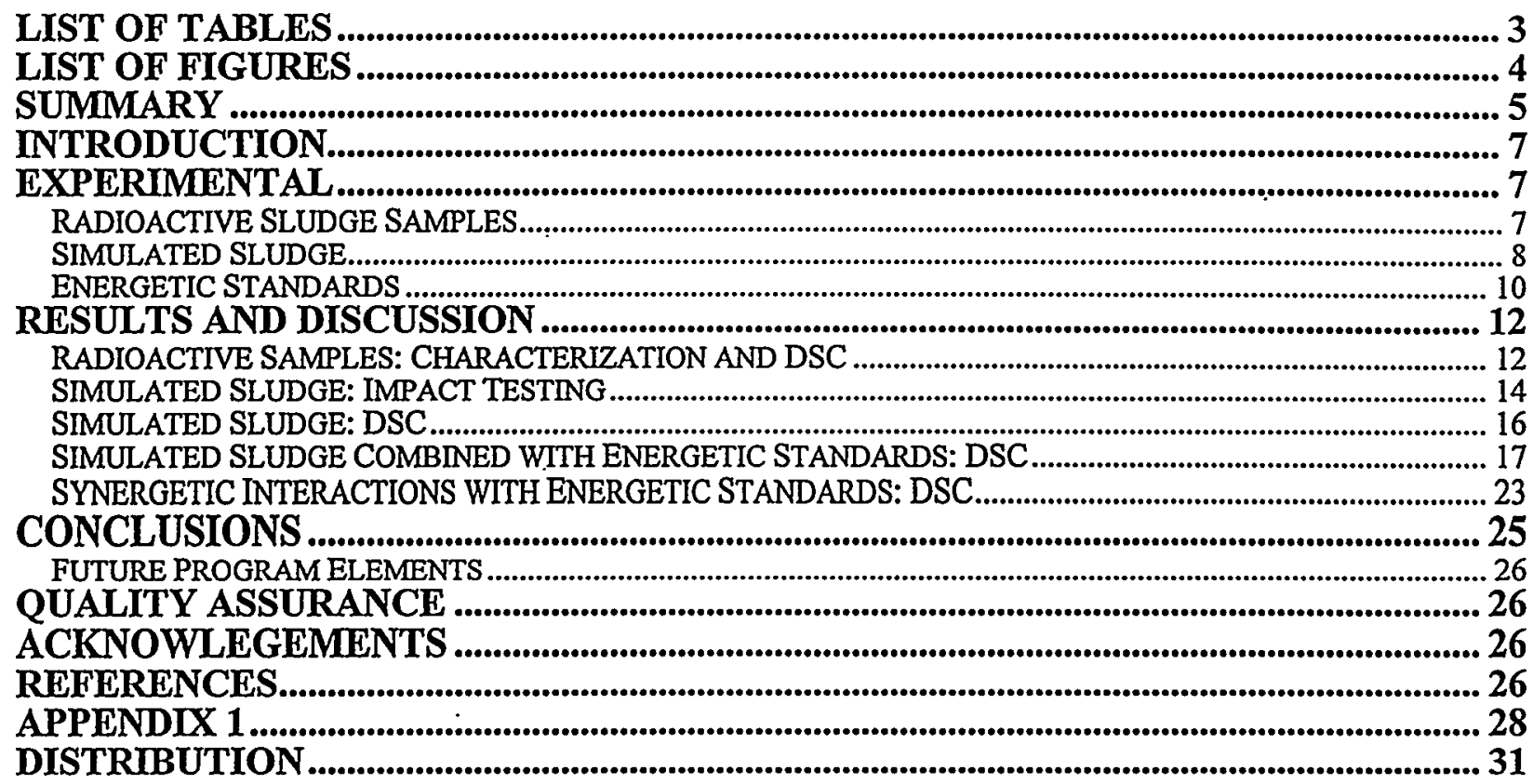

\section{LIST OF TABLES}

Table 1. Major elemental composition of Tank $15 \mathrm{H}$ radioactive sludge..................................9

Table 2. Additives and their range of concentration for addition to simulated sludge................ 9

Table 3. Exothermic properties of potential waste tank energetic compounds............................. 11

Table 4. Results of the Analysis of the Total Dried Solids from Archived Sludge Samples from Tanks $8 \mathrm{~F}, 12 \mathrm{H}$, and $15 \mathrm{H}$.

Table 5. Uranium and Plutonium Isotopics of the Total Dried Solids from Archived Sludge Samples from Tanks 8F, 12H, and 15H..................................................... 13

Table 6. Weight percent of explosives in simulated sludge mixtures...................................2 21

Table 7. Simulated sludge experimental design. .................................................................... 28

Table 8. Simulated sludge experimental design concentrations. ............................................28

Table 9. Experimental design of mercury oxalate and fulminate bearing simulated sludge compositions. ................................................................................................ 29

Table 10. Experimental concentrations of mercury oxalate and fulminate in simulated

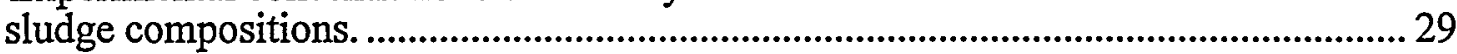

Table 11. Listing of impact tests.............................................................................................. 30

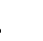
s .

\section{.} , (1) 16 政 .

\section{(6)}


WSRC-TR-98-00407

Page 4 of 31

November 2, 1998

\section{LIST OF FIGURES}

Figure 1. Archived sludge samples. From left to right, samples from Tanks 8F, $12 \mathrm{H}$ and $15 \mathrm{H}$.

Figure 2. Photographs of various simulated-sludge samples.

Figure 3. Detailed view of impact test chamber and impact (i.e., drop weight)

test equipment.

Figure 4. Calorimetry measurements -- replicate DSC spectra, left and center, and TGA

determination, right -- on archived Tank $15 \mathrm{H}$ sample.

Figure 5. Calorimetry measurements on archived Tank $8 \mathrm{~F}$ and Tank $12 \mathrm{H}$ samples.

Figure 6. Typical photos of impact test experiment. Left figure shows a test with no visible indication of reaction. Right figure depicts positive visible indication (i.e., smoke) of reaction.

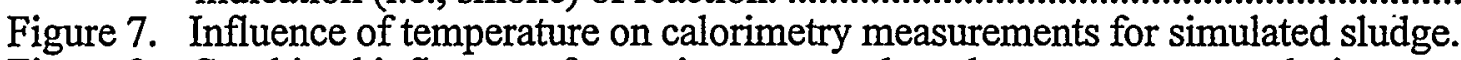

Figure 8. Combined influence of organic compounds and temperature on calorimetry measurements for simulated sludge.

Figure 9. Diffraction patterns for pure mercury oxalate.

Figure 10. Diffraction patterns for pure mercury fulminate.

Figure 11. Calorimetry measurements for energetic standards.

Figure 12. Calorimetry measurements of dry mercury oxalate added to dry sludge. ..................... 20

Figure 13. Calorimetry measurements of dry mercury oxalate added to wet sludge................... 20

Figure 14. Calorimetry measurements of dry mercury oxalate added to dry sludge containing organic compounds.

Figure 15. Calorimetry measurements of dry mercury fulminate added to dry sludge. ................. 22

Figure 16. Calorimetry measurements of dry mercury fulminate added to wet sludge................. 22

Figure 17. Calorimetry measurements of dry mercury fulminate added to dry sludge containing organic compounds.

Figure 18. Calorimetry measurements for mixture of mercury fulminate with various organic compounds.

Figure 19. Calorimetry measurement for a mixture of mercury oxalate and mercury fulminate. 


\section{SUMMARY}

This report details initial results from an investigation of the potential formation and fate of energetic compounds in Savannah River Site sludge. The initial studies included examination of archived sludge samples (from Tanks $8 \mathrm{~F}, 12 \mathrm{H}$, and $15 \mathrm{H}$ ) as well as calorimetry and impact testing of simulated sludge samples. The testing provide the following conclusions.

- Analysis of an archived Tank $12 \mathrm{H}$ and Tank $15 \mathrm{H}$ samples showed the material experienced prior treatment that makes it non-representative of the current contents of that vessel. In contrast, the composition of the archived Tank $8 \mathrm{~F}$ sample suggests no prior chemical treatment.

- The Differential Scanning Calorimetry (DSC) analysis of the Tank 8F, Tank $12 \mathrm{H}$ and Tank $15 \mathrm{H}$ samples showed no exothermic behavior to temperatures as high as $400^{\circ} \mathrm{C}$.

- Impact testing (with a pressure of $5.38 \mathrm{~N} / \mathrm{m}^{2}$, or $780 \mathrm{psi}$ ) of simulated sludge samples showed no visible evidence of exothermic reaction (i.e., smoke) at conservatively high concentrations of mercury and silver and after drying at a temperature of $50^{\circ} \mathrm{C}$. A test on a single sample dried at $350^{\circ} \mathrm{C}$ showed no indication of reaction.

- Calorimetric measurements of the same samples showed no indications of exothermic reaction. The lack of exothermic behavior suggests that unstable energetic compounds of mercury or silver do not readily form under the expected conditions for the alkaline sludge.

- The tests examined the influence of organic materials (i.e., sodium oxalate, Ionac 604 resin - either as received or after permanganate digestion, or a mixture of tri-n-butyl phosphate and n-paraffin) on these results. Adding these components at conservatively high concentrations did not result in any exothermic reactions as determined by both impact tests and calorimetry. The organic compounds do not appear to facilitate formation of energetic compounds in dried sludge.

The experiments also studied the behavior of mixtures of simulated sludge with mercury oxalate and with mercury fulminate. These two compounds decompose with moderately high release of energy when impacted or heated. These tests provide the following results.

- Impact testing with mixtures of simulated sludge containing as much as $14.9 \mathrm{wt} \%$ mercury oxalate or $21.5 \mathrm{wt} \%$ mercury fulminate showed no visible signs of reaction. The nominal mercury fulminate mass in 25 of 59 samples tested either equaled or exceeded the minimal amount of the pure mercury fulminate needed to produce a visible indication (i.e., smoke) for reaction with the impact test equipment. Similarly, 7 of 47 tests using a mixture of simulated sludge and mercury oxalate contained enough oxalate to exceed the detection as determined for the pure compound.

- Calorimetry measurements for mixtures of simulated dry sludge containing as much as $14.9 \mathrm{wt} \%$ of dry mercury oxalate showed no net exothermic behavior since the oxalate decomposition occurs at a temperature overlapping a region of endothermic behavior for the pure sludge. Review of the data suggests that the presence of the selected organic compounds did not alter the measurements. 
- Calorimetry of mixtures of wet sludge combined with mercury oxalate and then dried suggests negligible destruction of the oxalate in the alkaline media during the short contact and drying period.

- Calorimetry measurements for mixtures of simulated dry sludge containing as much as $21 \mathrm{wt} \%$ of mercury fulminate showed an exothermic reaction of magnitude roughly equivalent to that for the pure fulminate. Review of the data suggests that the presence of the selected organic compounds did not alter the measurements.

- Calorimetry of mixtures of wet sludge with approximately $1.68 \mathrm{wt} \%$ added mercury ${ }^{\circ}$ fulminate and then dried showed no detectable exothermic reactions. Increasing the fulminate concentration to $6.81 \mathrm{wt} \%$ resulted in a small exothermic reaction. Note that $6.81 \mathrm{wt} \%$ mercury fulminate equates to $120 \%$ of the mercury in Tank $15 \mathrm{H}$ converted entirely to the fulminate.

These experimental findings suggest the following conclusions of importance to storage and sampling efforts for dried sludge.

- Experimental evidence does not preclude the formation of energetic compounds in the waste tanks during dry storage. However, simulated sludge with conservatively high concentrations of mercury and silver failed to show any exothermic behavior without the deliberate addition of such compounds. Presence of conservatively high concentrations of several organic species did not alter this result.

- Both mercury oxalate and mercury fulminate survived contact with moist sludge ( $0.22 \mathrm{M}$ hydroxide) for periods as long as one day. Nevertheless, the mixtures of sludge with mercury oxalate showed no net exothermic behavior under the conservative conditions tested. Testing with mercury fulminate required addition at relatively high concentrations in simulated sludge to provide a relatively low energy exothermic reaction.

- Calorimetry data suggests the presence of the principal organic compounds of interest within simulated sludge does not enhance the energetic behavior of the material, even when both the organic and the energetic standard (i.e., mercury oxalate or mercury fulminate) exist in conservatively high concentrations.

The results of this study indicate that planned sampling of Tank $12 \mathrm{H}$ may proceed with minimal risk of experiencing an exothermic reaction during the sample collection.

Previous discussions suggested adding liquid to Tank $12 \mathrm{H}$ prior to sampling. Such an addition will reduce the concentration of dust - with associated radionuclides - in the tank vapor space during the sampling evolution. The liquid would also provide a means to dissipate any energy released during sampling. However, an excess addition of liquid could jeopardize the integrity of the collected sample from the perspective of determining whether energetic compounds exist during dry storage.

Future efforts should extend the studies to large masses of simulated sludge. Similarly, testing should examine the influence of extended contact to caustic on the energetic behavior of selected compounds such as mercury oxalate, mercury fulminate, and silver nitride. Additional calorimetry studies should further examine the behavior of simulated sludge with mixtures of 
energetic standards, for instance, to include the combined presence of silver nitride and mercury oxalate.

\section{INTRODUCTION}

The Savannah River Site stores High Level Waste in several forms in large carbon steel tanks. One of those forms consists primarily of insoluble iron and aluminum oxides with smaller amounts of uranium, manganese, mercury and nickel and traces of various radionuclides. Trace amounts of silver compounds also exist in the tank farm from transfers in the late 1960s of silver Berl saddles used as part of the canyon process. Ordinarily an aqueous supernate layer remains over the top of the sludge. A previous study indicated that when sludge remains in a wet state, little concern exists for any sort of energetic decomposition. ${ }^{1}$ However, recent operations allowed several of the sludge tanks to dry, at least on the surface. A concern exists that certain mercury. and silver compounds and mixtures of organic compounds and nitrates capable of energetic decomposition may form in the dry sludge. Also, such materials generally become more reactive when dry. High Level Waste Division requested the assistance of the Savannah River Technology Center (SRTC) in determining the likelihood for the energetic decomposition during sampling of the dry sludge. ${ }^{2,3}$ This report documents initial studies to determine whether energetic compounds exist in the dry sludge in sufficient quantities to pose a safety concern.

\section{EXPERIMENTAL}

\section{Radioactive Sludge Samples}

For Tanks $8 \mathrm{~F}, 12 \mathrm{H}$, and $15 \mathrm{H}$ each containing dry sludge, archived samples existed in the Shielded Cells of Building 773-A, Figure 1. Original collection of the samples occurred on September 26, June 16, and May 11 of 1977, respectively. However, review of existing records and interviews with personnel failed to provide a definitive understanding of the history for these samples. Researchers could not determine from this review whether the samples received treatment in previous years. Even if previously treated, these samples, dried over an extensive period of time, might still provide insight regarding formation of any energetic compounds during drying. If previously treated and left with a less alkaline supernate, the conditions might prove more favorable to generating these unstable species. ${ }^{4}$ Therefore, personnel analyzed these samples to determine how well they represent the current content of the tanks.

Personnel dissolved portions of the dried samples in triplicate by contacting with aqua regia or by fusion with sodium peroxide. Contacting the sodium peroxide fusion with nitric acid allows determination of the composition of the total sample. For both radiological protection and analytical limitations, the analyses required dilution of the digested sludge samples with deionized, distilled water before analysis. 


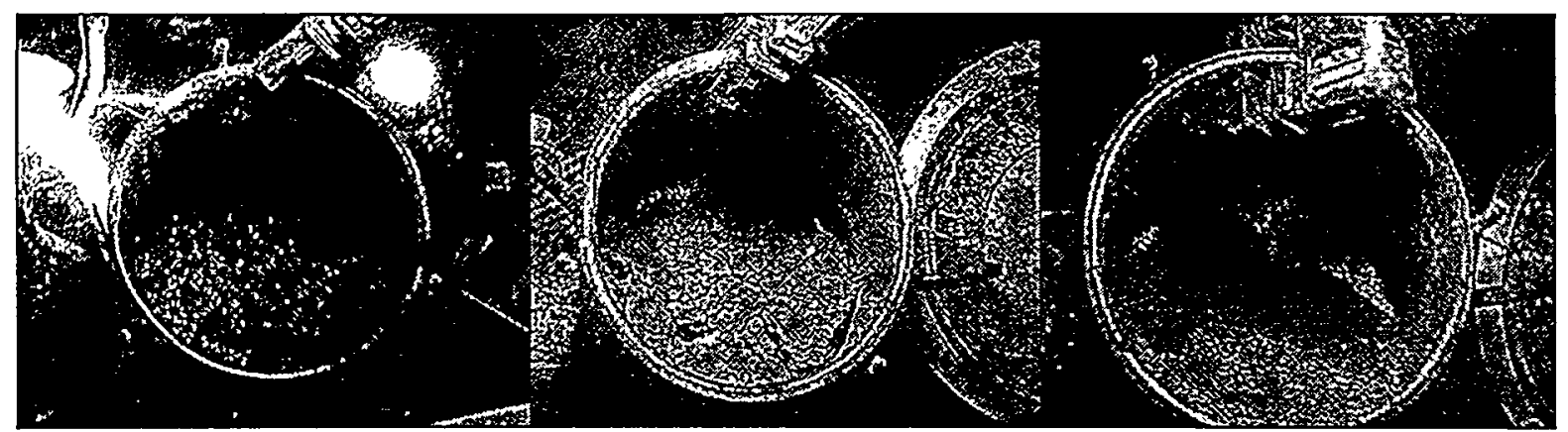

Figure 1. Archived sludge samples. From left to right, samples from Tanks $8 \mathrm{~F}, 12 \mathrm{H}$ and $15 \mathrm{H}$.

The Analytical Development Section uses the following analytical methods for determination of specific species. Measurement of sodium, aluminum, iron, and other metallic elements used inductively coupled plasma-emission spectroscopy (ICP-ES). Potassium and mercury determinations used atomic adsorption spectroscopy (AA) with the mercury measurement using the cold-vapor technique (CV). Noble metals (i.e., $\mathrm{Ag}, \mathrm{Rh}, \mathrm{Ru}$, and $\mathrm{Pd}$ ) concentrations came from inductively-coupled plasma mass spectrometry (ICP-MS). Gamma spectroscopy provided the concentrations of gamma-emitting fission products. Actinide concentrations derive from a combination of ICP-MS and alpha counting spectroscopy. Personnel determined the $\mathrm{Sr}^{90}$ content from the beta liquid scintillation counting with strontium separation on selected samples as necessary.

Researchers performed differential scanning calorimetry and thermal gravimetric analysis (TGA) on portions of the Tank 15H sample. (Calibration of the TA Instruments 910 Differential Scanning Calorimeter used the melting point of zinc as a standard. The TGA experiments used calcium oxalate decomposition as a standard.) For samples from Tanks $8 \mathrm{~F}$ and $12 \mathrm{H}$, researchers only performed the calorimetry measurement. These thermal methods allow identification of any exothermic reactions and associated sample weight loss that occurs when heating a sample. Most energetic compounds exhibit thermal instability, often at relatively low temperatures.

\section{Simulated Sludge}

Table 1 shows the chemical composition of the Tank $15 \mathrm{H}$ sludge as previously determined by Coleman et al. ${ }^{5}$ Researchers used this composition in developing a simulated sludge to serve as a reference material. Testing added mercury, silver, digested resin, undigested resin, sodium oxalate and a mixture of tri-n-butyl phosphate and n-paraffin to this simulated sludge (see Table 2 for range of each variable). Appendix 1 provides a listing of the individual experiments. The synthesis of the sludge also used a supernate containing $0.22 \mathrm{M}$ hydroxide, $1.3 \mathrm{M}$ nitrate, $0.86 \mathrm{M}$ nitrite, and $0.08 \mathrm{M}$ aluminate. This supernate composition approximates that measured for Tank $15 \mathrm{H}$ in September of $1983 .^{6}$ Personnel dried these various sludge samples to a constant weight using a range of drying temperatures (i.e., $50 \pm 3,150 \pm 3,250 \pm 3$, and $350 \pm 5^{\circ} \mathrm{C}$ ). Drying times ranged from 16 to 89 hours. (Researchers checked the samples infrequently for dryness and hence recorded drying time does not correlate with completion of drying.) The highest temperature matches the maximum temperature ever experienced in a waste tank (i.e., Tank $1 \mathrm{~F}$ during November, 1964). ${ }^{7}$ See Figure 1 for views of the resulting sludge samples. 
Table 1. Major elemental composition of Tank $15 \mathrm{H}$ radioactive sludge.

\begin{tabular}{|c|c|c|c|}
\hline Element & $\begin{array}{l}\text { Concentration } \\
\text { (elemental wt \%) }\end{array}$ & Element & $\begin{array}{l}\text { Concentration } \\
\text { (elemental wt }\end{array}$ \\
\hline $\mathrm{Fe}$ & 4.9 & $\frac{\mathrm{p}}{\mathrm{P}}$ & 0.30 \\
\hline $\mathrm{Al}$ & 30.8 & $\mathrm{Ni}$ & 0.46 \\
\hline $\mathrm{Na}$ & 2.4 & $\mathrm{Cu}$ & 0.05 \\
\hline $\mathrm{K}$ & 0.0 & $\mathrm{Ti}$ & 0.02 \\
\hline $\mathrm{Mn}$ & 2.5 & $\mathrm{Cr}$ & 0.02 \\
\hline U & 0.045 & $\mathrm{Th}$ & 0.23 \\
\hline $\mathrm{Ca}$ & 0.21 & $\mathrm{Ru}$ & 0.064 \\
\hline $\mathrm{Mg}$ & 0.15 & $\mathrm{Rh}$ & 0.013 \\
\hline $\mathrm{Si}$ & 0.19 & $\mathrm{Pd}$ & 0.002 \\
\hline $\mathbf{P}$ & 0.01 & & \\
\hline
\end{tabular}

Table 2. Additives and their range of concentration for addition to simulated sludge.

$$
\begin{aligned}
& \text { Nominal } \\
& \text { Tank } 15 \mathrm{H} \\
& \text { Additive } \quad \underline{\text { Concentration }} \text { Range } \quad \text { Basis/Comment } \\
& \text { Mercury } \quad 4 \mathrm{wt} \% \quad 0-6 \mathrm{wt} \% \quad \text { Upper limit of } 1.5 \text { times } \\
& \text { Silver } \quad 0.0003 \mathrm{wt} \% \quad 0-0.0015 \mathrm{wt} \% \quad \text { Upper limit of } 5 \text { times } \\
& \text { Digested resin Undetermined } \quad 0-3 \mathrm{wt} \% \quad \text { Selected to exceed highest } \\
& \text { expected content based on } \\
& \text { process knowledge } \\
& \text { Undigested resin Undetermined } \quad 0-3 \mathrm{wt} \% \quad \text { Selected to exceed highest } \\
& \text { expected content based on } \\
& \text { process knowledge } \\
& \text { Tri-n-butyl Undetermined } \quad 0-3 \mathrm{wt} \% \quad \text { Selected to exceed highest } \\
& \text { Phosphate expected content based on } \\
& (30 \mathrm{vol} \%) \text { and } \mathrm{n} \text { - process knowledge } \\
& \text { paraffin mixture } \\
& \text { Sodium oxalate. Undetermined } 0-3 \mathrm{wt} \% \text { Selected to exceed highest } \\
& \text { expected content based on } \\
& \text { - process knowledge }
\end{aligned}
$$




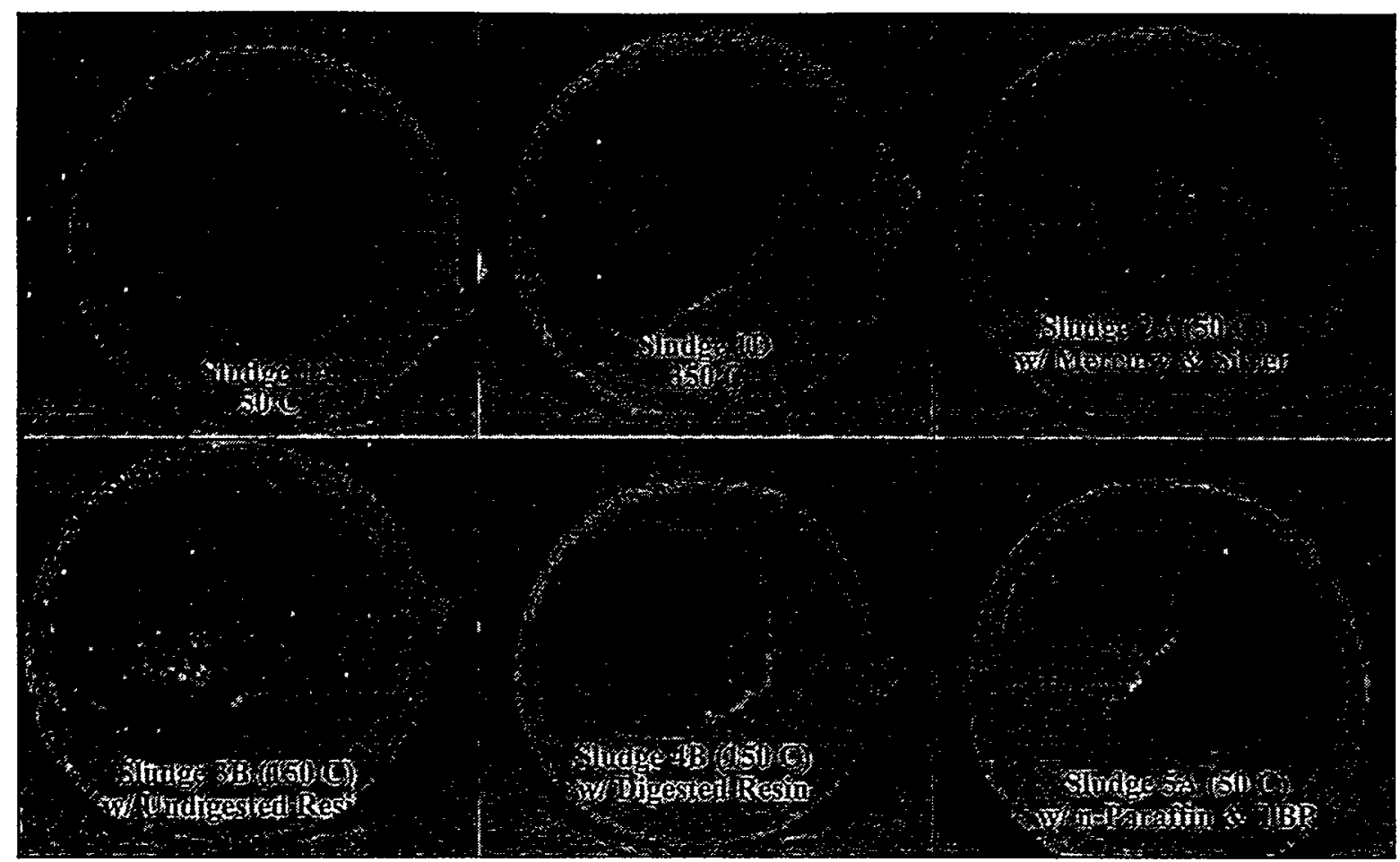

Figure 2. Photographs of various simulated-sludge samples.

After preparation, personnel examined the simulated sludge using standard impact tests. ${ }^{9,10}$ Figure 3 and shows the equipment used for these tests. These tests resemble similar studies of Hanford High Level Waste material reported in the past from Los Alamos National Laboratory. ${ }^{11}$ Personnel also examined the dried samples for energetic reactions at temperatures to $400^{\circ} \mathrm{C}$ using DSC and TGA methods.

\section{Energetic Standards}

Hobbs ${ }^{4}$ evaluated known energetic compounds for use as standards in these experiments and recommended any of the following: silver nitride $\left(\mathrm{Ag}_{3} \mathrm{~N}\right)$, mercury (II) fulminate $\left(\mathrm{Hg}(\mathrm{ONC})_{2}\right)$, mercury oxalate, and Millon's base $\left(\mathrm{Hg}_{2} \mathrm{NOH}^{*} 2 \mathrm{H}_{2} \mathrm{O}\right)$ or a derivative. Table 3 gives the energies associated with the decomposition of several of these compounds. Given that the mercury concentration far exceeds than of silver in the waste, personnel synthesized two of these compounds for use as standards: mercury oxalate and mercury fulminate. ${ }^{12}$ Oxalate preparation involved precipitation from a dilute nitric acid solution saturated in mercuric nitrate. The fulminate synthesis involved direct reaction of a strongly acidic mercuric nitrate solution with ethyl alcohol. Personnel verified the synthesis by performing x-ray diffraction and Raman spectroscopy on the solids. 


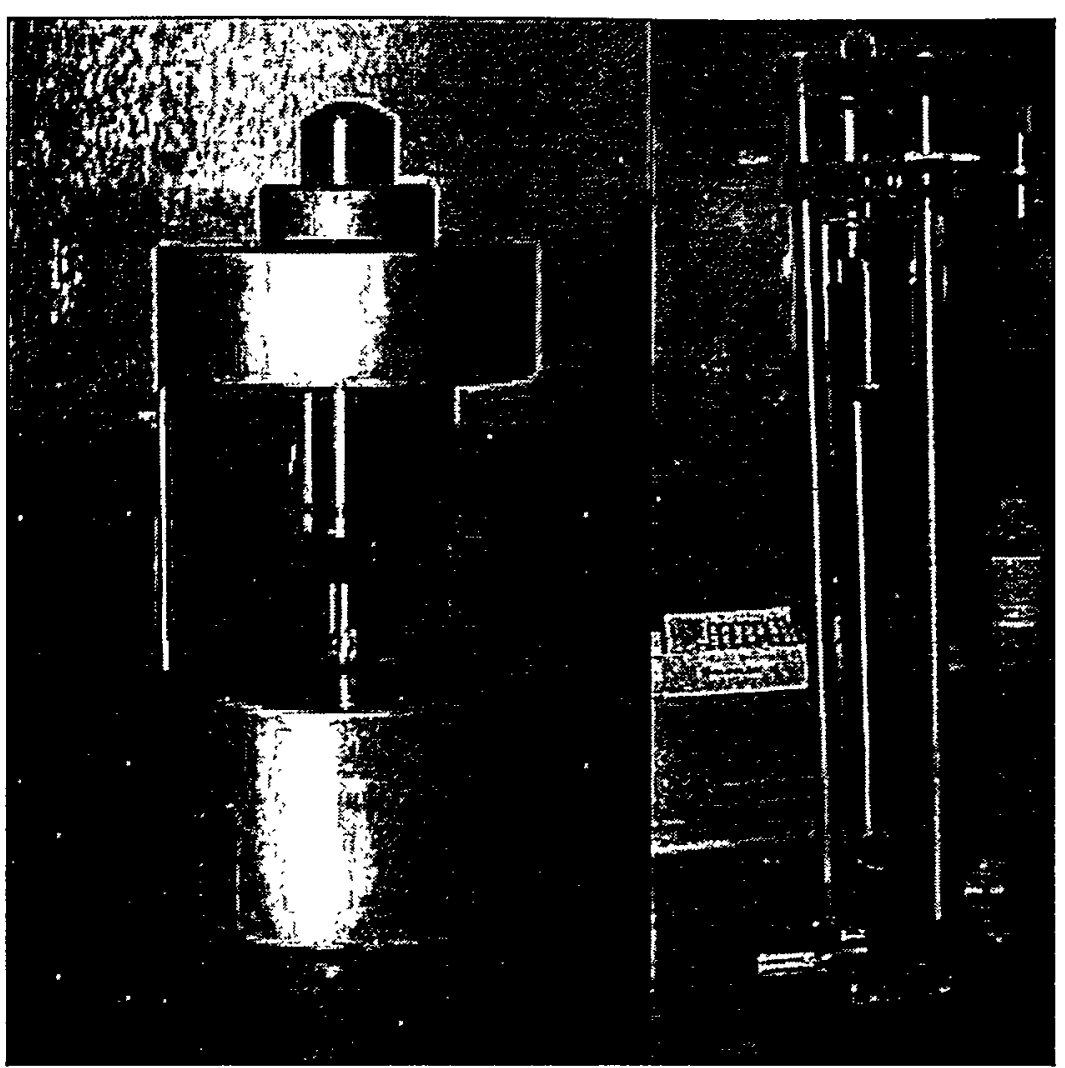

Figure 3. Detailed view of impact test chamber and impact (i.e., drop weight) test equipment.

Table 3. Exothermic properties of potential waste tank energetic compounds.

Mercury fulminate ${ }^{13}$

$$
\begin{array}{ll}
\text { Heat of explosion } & 1486 \mathrm{~J} / \mathrm{g} \\
\text { Decomposition temperature } & 165^{\circ} \mathrm{C}
\end{array}
$$

Mercury oxalate ${ }^{14}$

$\begin{array}{ll}\text { Decomposition energy } & 377 \mathrm{~J} / \mathrm{g} \\ \text { Decomposition temperature } & 1722^{\circ} \mathrm{C}\end{array}$

Silver oxalate ${ }^{14}$

$$
\begin{array}{ll}
\text { Decomposition energy } & 372 \mathrm{~J} / \mathrm{g} \\
\text { Decomposition temperature } & 136{ }^{\circ} \mathrm{C}
\end{array}
$$

Silver nitride ${ }^{15}$

$$
\begin{array}{ll}
\text { Decomposition energy } & 1860 \mathrm{~J} / \mathrm{g} \\
\text { Decomposition temperature } & 270^{\circ} \mathrm{C} \text { (in presence of impurities) } \\
& 340^{\circ} \mathrm{C} \text { (pure) }
\end{array}
$$

Trinitrotoluene (TNT - for comparative purposes ${ }^{13}$ )

$$
\begin{array}{ll}
\text { Decomposition energy } & 4560 \mathrm{~J} / \mathrm{g} \\
\text { Decomposition temperature } 300^{\circ} \mathrm{C}
\end{array}
$$


WSRC-TR-98-00407

Page 12 of 31

November 2, 1998

\section{RESULTS AND DISCUSSION}

\section{Radioactive Samples: Characterization and DSC}

Table 4 and Table 5 provide the currently available results of the chemical analyses. Sodium and aluminum concentrations provide the primary insight into process history for the samples. The sample from Tank $8 \mathrm{~F}$ shows a high sodium and low aluminum concentration such as expected based on process history. However, the samples from Tanks $12 \mathrm{H}$ and $15 \mathrm{H}$ contain much less sodium and more aluminum by comparison, suggesting previous sample handling included caustic leaching and washing. Hence, the Tank $8 \mathrm{~F}$ appears to more closely resemble current vessel contents.

Figure 4 provides the DSC and TGA results for the archived Tank $15 \mathrm{H}$ material. Figure 5 provides the DSC results for the archived Tank $8 \mathrm{~F}$ and Tank $12 \mathrm{H}$ samples. The DSC spectra provide the specific energy released as the material heats to a defined temperature. (For the simulated sludge samples that follow, the line continues through the cooling of the sample.) The experiments start with the material at a low temperature - typically $40^{\circ} \mathrm{C}$ for these experiments and raise the temperature at a pre-selected rate, generally $10^{\circ} \mathrm{C} / \mathrm{min}$ in this work. Most testing held the samples in air although a few used an argon cover gas. A smooth horizontal line represents the lack of a reaction or heat flow from the material. A line deviating to negative energy flow represents either an endothermic reaction or a phase transition. For instance, near $100^{\circ} \mathrm{C}$ most samples evaporate water requiring a heat input to remove the water. When solids undergo a phase transition - such as melting to changing crystal structure - an endothermic peak occurs. On cooling, such reversible phase transitions show an exothermic (i.e., positive energy flow) peak: see Figure 7 above $200^{\circ} \mathrm{C}$. An explosion shows a very strong exothermic peak, narrow in width. The strongest such reactions will often exceed the ability of the equipment to track the energy flow.

These samples showed no evidence of exothermic reactions. Several broader endothermic peaks occur on the calorimetry scans (i.e., centered near temperatures of 55, 130-150, 230, 240,280, and beyond $300{ }^{\circ} \mathrm{C}$ ). During sample preparation, personnel did not observe any sparks or evidence of shock-sensitive compounds (although the remote operations make such observations difficult except for the most energetic of reactions).

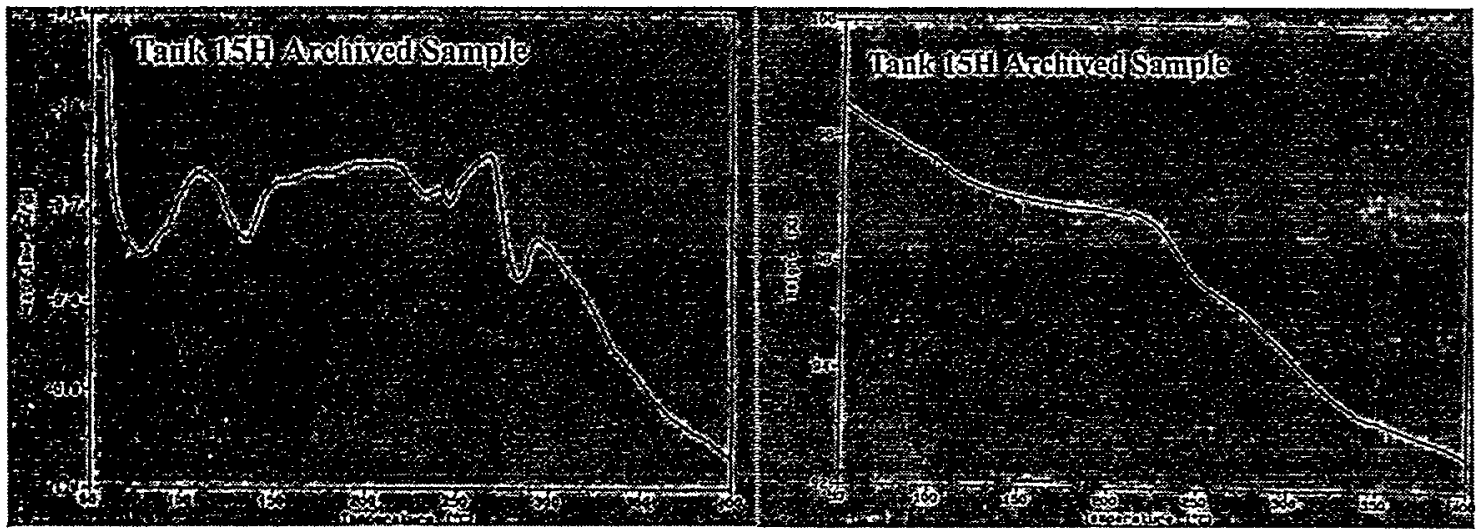

Figure 4. Calorimetry measurements -- DSC spectra, left, and TGA right -- of archived Tank 15H sample. 
WSRC-TR-98-00407

Page 13 of 31

November 2, 1998

Table 4. Results of the Analysis of the Total Dried Solids from Archived Sludge Samples from Tanks $8 \mathrm{~F}, 12 \mathrm{H}$, and $15 \mathrm{H}$.

\begin{tabular}{|c|c|c|c|c|}
\hline Species & & $\begin{array}{l}\text { Archived Tank } \\
\text { 8F Sludge }\end{array}$ & $\begin{array}{l}\text { Archived Tank } \\
\text { 12H Sludge }\end{array}$ & $\begin{array}{l}\text { Archived Tank } \\
\text { 15H Sludge }{ }^{\mathrm{a}}\end{array}$ \\
\hline $\mathrm{Fe}$ & wt \% & $19.3(5)$ & $4.12(9)$ & $4.03(8)$ \\
\hline $\mathrm{Na}$ & wt \% & $11.8(7)$ & $1.57(7)$ & $2.51(7)$ \\
\hline $\mathrm{Al}$ & wt \% & $3.01(7)$ & $33.1(4)$ & $30.1(2)$ \\
\hline U & wt \% & $11.5(2)$ & $0.044(5)$ & $0.013(2)$ \\
\hline $\mathrm{Mn}$ & wt \% & $3.75(4)$ & $1.95(2)$ & $2.43(4)$ \\
\hline $\mathrm{Ca}$ & wt \% & $1.52(2)$ & $1.12(1)$ & $0.23(15)$ \\
\hline $\mathrm{Mg}$ & wt \% & $0.32(7)$ & $0.18(14)$ & $0.15(6)$ \\
\hline $\mathrm{Si}$ & wt $\%$ & $<1$ & $<1$ & $0.18(2)$ \\
\hline $\mathrm{P}$ & wt \% & $<0.3$ & $<0.3$ & $0.27(15)$ \\
\hline $\mathrm{Ni}$ & wt \% & $3.78(6)$ & $0.52(9)$ & $0.42(5)$ \\
\hline $\mathrm{Cr}$ & wt \% & $0.085(13)$ & $<0.07$ & $0.015(7)$ \\
\hline $\mathrm{Hg}$ & wt \% & $0.46(2)$ & $0.92(6)$ & $3.32(3)$ \\
\hline $\mathrm{Cu}$ & wt \% & $0.080(7)$ & $<0.07$ & $0.042(14)$ \\
\hline $\mathrm{Ti}$ & wt \% & $<0.03$ & $<0.03$ & 0.014 (18) \\
\hline $\mathrm{Pu}$ & wt.\% & $0.013(3)$ & $0.031(7)$ & $0.0019(6)$ \\
\hline $\mathrm{Ag}$ & wt \% & $*$ & $*$ & Not detected \\
\hline $\mathrm{Pd}$ & wt \% & * & $*$ & $0.00047(13)$ \\
\hline $\mathrm{Ru}$ & wt \% & * & $*$ & $0.059(3)$ \\
\hline $\mathrm{Rh}$ & wt \% & $*$ & $*$ & $0.014(3)$ \\
\hline $\mathrm{K}$ & & $<0.2$ & $<0 . \dot{2}$ & $<0.2$ \\
\hline $\mathrm{Sr}^{90}$ & $\mu \mathrm{Ci} / \mathrm{g}$ & $1.70 \mathrm{E}+04(6)$ & $1.51 \mathrm{E}+04(4)$ & $1.47 \mathrm{E}+04(3)$ \\
\hline $\mathrm{Cs}^{137}$ & $\mu \mathrm{Ci} / \mathrm{g}$ & $101(3)$ & $88.2(3)$ & $85.6(6)$ \\
\hline $\mathrm{Am}^{241}$ & $\mu \mathrm{Ci} / \mathrm{g}$ & $85.3(11)$ & $32.9(3)$ & $6.51(13)$ \\
\hline $\mathrm{Eu}^{154}$ & $\mu \mathrm{Ci} / \mathrm{g}$ & $36.1(7)$ & $67.9(4)$ & $78.6(12)$ \\
\hline $\mathrm{Co}^{60}$ & $\mu \mathrm{Ci} / \mathrm{g}$ & $32.0(7)$ & $1.54(5)$ & $1.30(4)$ \\
\hline $\mathrm{Eu}^{155}$ & $\mu \mathrm{Ci} / \mathrm{g}$ & $30.6(7)$ & $10.2(6)$ & 9.34 (14) \\
\hline
\end{tabular}

aValue in parenthesis indicates percent relative standard deviation of three or more determinations on aliquots of the same sample. This deviation provides a measure of the analytical precision and does not account for the sampling uncertainty.

*Analysis pending.

Table 5. Uranium and Plutonium Isotopics of the Total Dried Solids from ArchivetSludge Samples from Tanks 8F, 12H, and 15H. 
WSRC-TR-98-00407

Page 14 of 31

November 2, 1998

\begin{tabular}{lcccc} 
Species & & $\begin{array}{c}\text { Archived Tank } \\
\text { 8F Sludge }\end{array}$ & $\begin{array}{c}\text { Archived Tank } \\
\text { 12H Sludge }\end{array}$ & $\begin{array}{c}\text { Archived Tank } \\
\text { 15H Sludge }\end{array}$ \\
\hline $\mathrm{U}^{233}$ & wt \% & Not detected & $1.5 \mathrm{E}-03(7)$ & $3.1 \mathrm{E}-04(22)$ \\
$\mathrm{U}^{234}$ & wt \% & $3.3 \mathrm{E}-04(15)$ & $1.0 \mathrm{E}-03(6)$ & $2.9 \mathrm{E}-04(42)$ \\
$\mathrm{U}^{235}$ & wt \% & $3.6 \mathrm{E}-02(3)$ & $5.3 \mathrm{E}-03(1)$ & $4.4 \mathrm{E}-03(2)$ \\
$\mathrm{U}^{236}$ & wt \% & $2.0 \mathrm{E}-03(5)$ & $1.7 \mathrm{E}-03(4)$ & $1.9 \mathrm{E}-03(8)$ \\
$\mathrm{U}^{238}$ & wt \% & $1.14 \mathrm{E}+01(2)$ & $3.5 \mathrm{E}-02(6)$ & $5.7 \mathrm{E}-03(6)$ \\
$\mathrm{U}^{\text {total }}$ & wt \% & $1.15 \mathrm{E}+01(2)$ & $4.4 \mathrm{E}-02(5)$ & $1.3 \mathrm{E}-02(2)$ \\
& & & & \\
$\mathrm{Pu}^{238}$ & wt \% & $1.9 \mathrm{E}-04(50)$ & $5.0 \mathrm{E}-03(10)$ & $6.1 \mathrm{E}-04(8)$ \\
$\mathrm{Pu}^{239}$ & wt \% & $9.8 \mathrm{E}-03(3)$ & $2.0 \mathrm{E}-02(4)$ & $1.2 \mathrm{E}-03(9)$ \\
$\mathrm{Pu}^{240}$ & wt \% & $1.4 \mathrm{E}-03(10)$ & $4.2 \mathrm{E}-03(5)$ & $2.1 \mathrm{E}-04(16)$ \\
$\mathrm{Pu}^{241}$ & wt \% & $1.5 \mathrm{E}-03(17)$ & $9.0 \mathrm{E}-04(69)$ & Not detected \\
$\mathrm{Pu}^{242}$ & wt \% & Not detected & $3.5 \mathrm{E}-04(19)$ & Not detected \\
$\mathrm{Pu}^{\text {total }}$ & wt \% & $1.3 \mathrm{E}-02(3)$ & $3.1 \mathrm{E}-02(7)$ & $2.0 \mathrm{E}-03(6)$ \\
$\mathrm{V}$
\end{tabular}

Values in parenthesis indicate percent relative standard deviation of three or more determinations on aliquots of the same sample. This is a measure of the analytical precision and does not account for the sampling uncertainty.

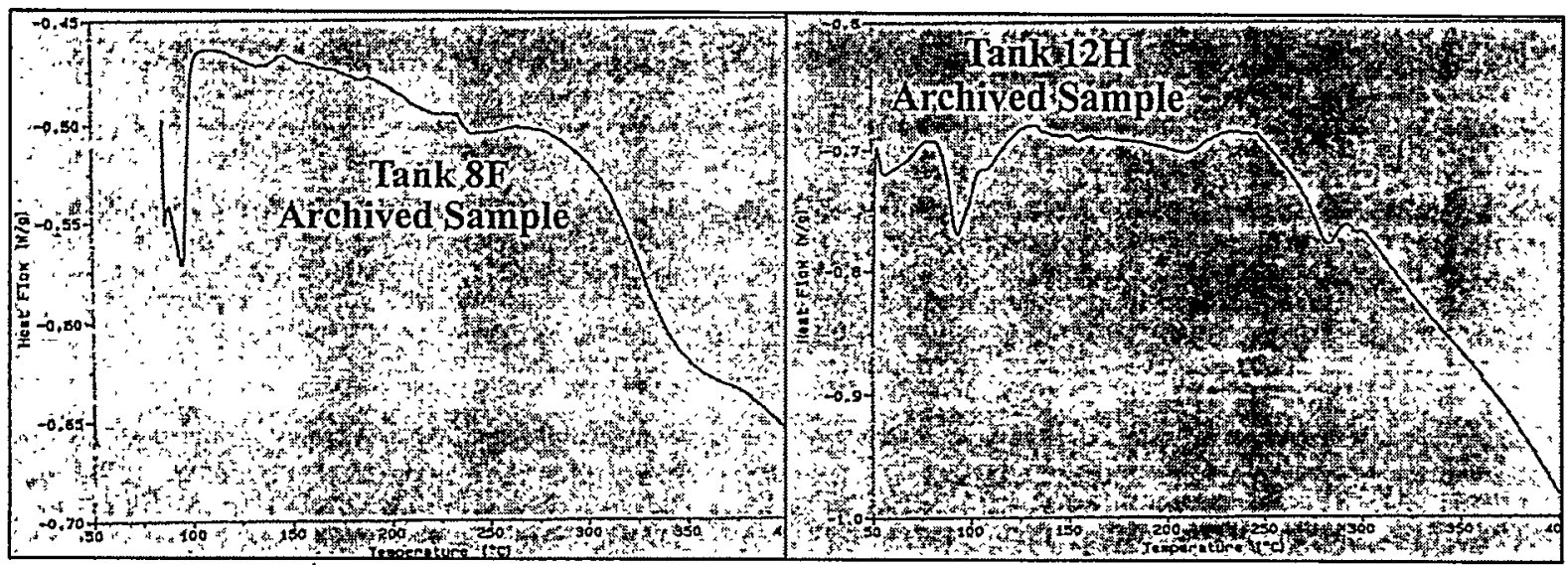

Figure 5. Calorimetry measurements on archived Tank $8 \mathrm{~F}$ and Tank $12 \mathrm{H}$ samples.

\section{Simulated Sludge: Impact Testing}

Impact testing of all sludge samples provided no. indication of exothermic reaction or shock sensitive compounds. Such testing generally included multiple - typically five or six-attempts with the same materials. Testing also examined the response with the addition of either mercury 
oxalate or mercury fulminate in the sludge materials. With oxalate concentrations as high as 15 wt \% (nominal), the tests showed no signs of an exothermic reaction. Similarly, with mercury fulminate added at concentrations as high as $15 \mathrm{wt} \%$ (nominal), the experiments did not indicate a reaction upon impact.

Observation of a reaction using the impact test protocol proves subjective with relatively high detection limits. Researchers also tested the pure standards and attempted to define the minimum amount required to provide a positive indication of reaction. Figure 6 shows the results of such a test yielding a reaction. The smoke observed in the figure provided the only reliable means of detection. For mercury oxalate, testing required $3 \mathrm{mg}$ to achieve a visible result. For mercury fulminate, personnel noted a reaction for masses as small as $2 \mathrm{mg}$. (When using small total masses of the compounds, researchers occasionally added a layer of an inert material, sodium nitrate, underneath the standard to improve contact with the falling piston.) These detection limits for pure materials imply a minimal detection limit for samples containing sludge mixed with the mercury compounds. For sludge containing mercury oxalate, the method could detect an explosion in a sludge mixture containing at least $15 \mathrm{wt} \%$ mercury oxalate. Similarly, the method could detect a reaction for a sludge mixture containing at least $10 \mathrm{wt} \%$ of mercury fulminate.

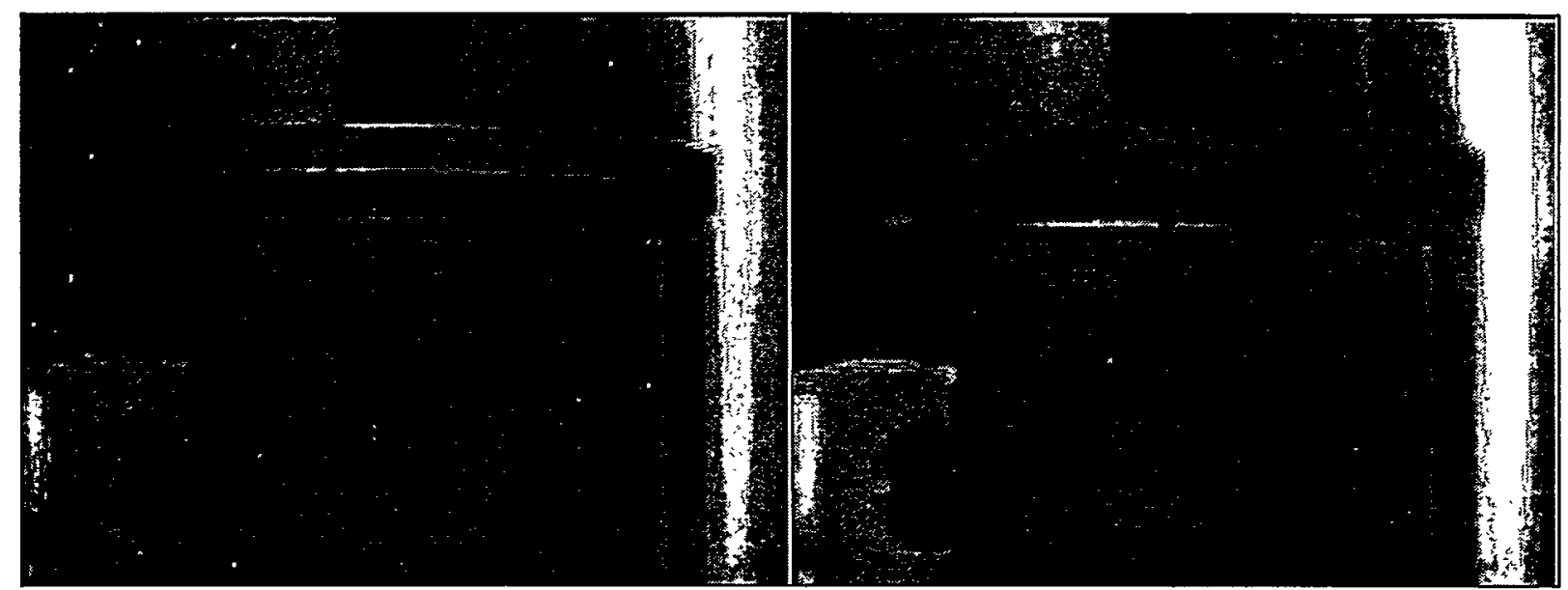

Figure 6. Typical photos of impact test experiment. Left figure shows a test with no visible indication of reaction. Right figure depicts positive visible indication (i.e., smoke) of reaction.

Researchers investigated various means to improve detection beyond that available by visible observation. In one case, personnel used a mercury specific detector (Jerome Model 411 Mercury Vapor Analyzer). This detector senses the presence of mercury vapor by means of a gold detection plate that amalgamates with the mercury. Detection limits measure as low as $0.001 \mu \mathrm{g} / \mathrm{L}$ of air: Personnel attempted to direct the gases from the impact test unit into the detector by a simple funnel. The use of the equipment inside a forced flow hood limited the ability to provide reproducible results. For the standards, even at amounts as low as $3 \mathrm{mg}$ mercury oxalate, the concentrations detected exceed the maximum range (i.e., $1.99 \mu \mathrm{g} / \mathrm{L}$ ) of the instrument. For impact tests of sludge mixtures containing no standards but with 6 wt $\%$ mercury, the instrument did not detect mercury vapor above the background for the equipment when using no material (i.e., $0.030 \mu \mathrm{g} / \mathrm{L}$ ). For sludge samples with added mercury oxalate or mercury fulminate, the method gave intermediate and non-reproducible results. 
WSRC-TR-98-00407

Page 16 of 31

November 2, 1998

Personnel also performed visual microscopy on samples following testing. For the pure standards, the microscopy detected droplets of mercury formed during the decomposition reaction. For the sludge samples, personnel could not visually detect any such droplets. However, the detection limit for this microscopic method remains unknown.

\section{Simulated Sludge: DSC}

Figure 7 (experimental Series 1) shows the influence of drying temperature on the energetic characteristics of the sludge samples that did not contain organic compounds, silver or mercury. As the drying temperature changed from 50 to $350^{\circ} \mathrm{C}$ for the sludge, the thermal characteristics -remained largely unchanged. Addition of mercury and silver in Series 2 (not shown), at conservatively high concentrations, in the sludge sample prior to drying did not alter this observation. None of these tests showed, during heating, any indication of an exothermic reaction by DSC at temperatures as high as $400^{\circ} \mathrm{C}$. Between 300 and $220^{\circ} \mathrm{C}$, exothermic peaks

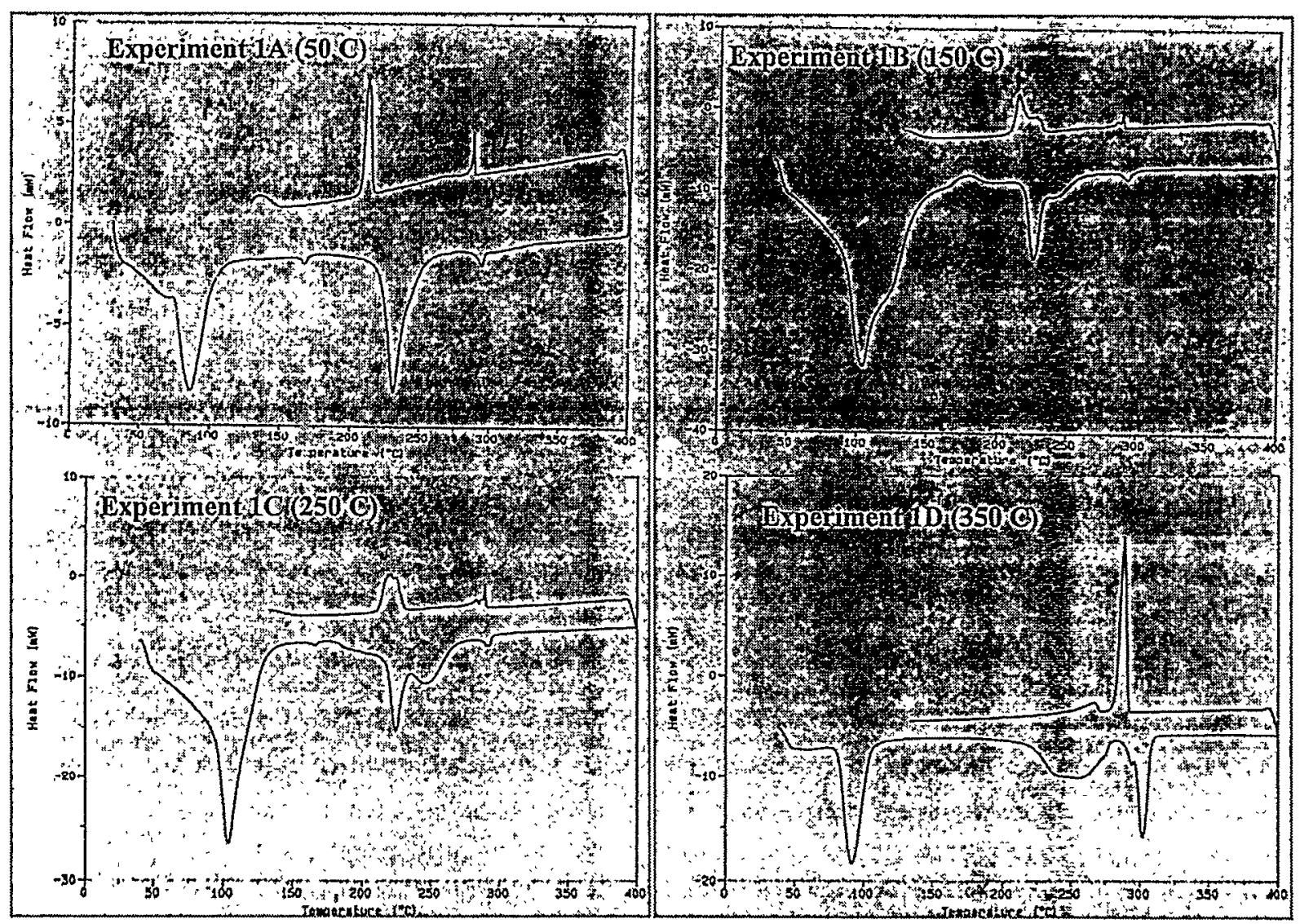

Figure 7. Influence of temperature on calorimetry measurements for simulated sludge.

occur during cooling at approximately similar temperatures for endothermic peaks during heating. These pairs likely represent changes in crystalline phases of alumina compounds. ${ }^{16}$

Figure 8 provides insight into the combined influence of organic compounds and drying temperature. Experimental Series 7 did not include mercury or silver in the sludge recipes. Thermal analyses of these samples again showed no exothermic reactions. The endothermic behavior at temperatures below $100^{\circ} \mathrm{C}$ and near $250^{\circ} \mathrm{C}$ broadened relative to observations in the 
WSRC-TR-98-00407

Page 17 of 31

November 2, 1998

absence of the organic compounds. As the drying temperature of the sludge sample increased, additional endothermic peaks occur in the figures, presumably from partial thermal decomposition of the organic compounds during drying. Although not shown, experiments also examined the influence of each individual organic compound (Series 3 through Series 6). Again, tests with the individual organic compounds added did not result in any indication of exothermic behavior.

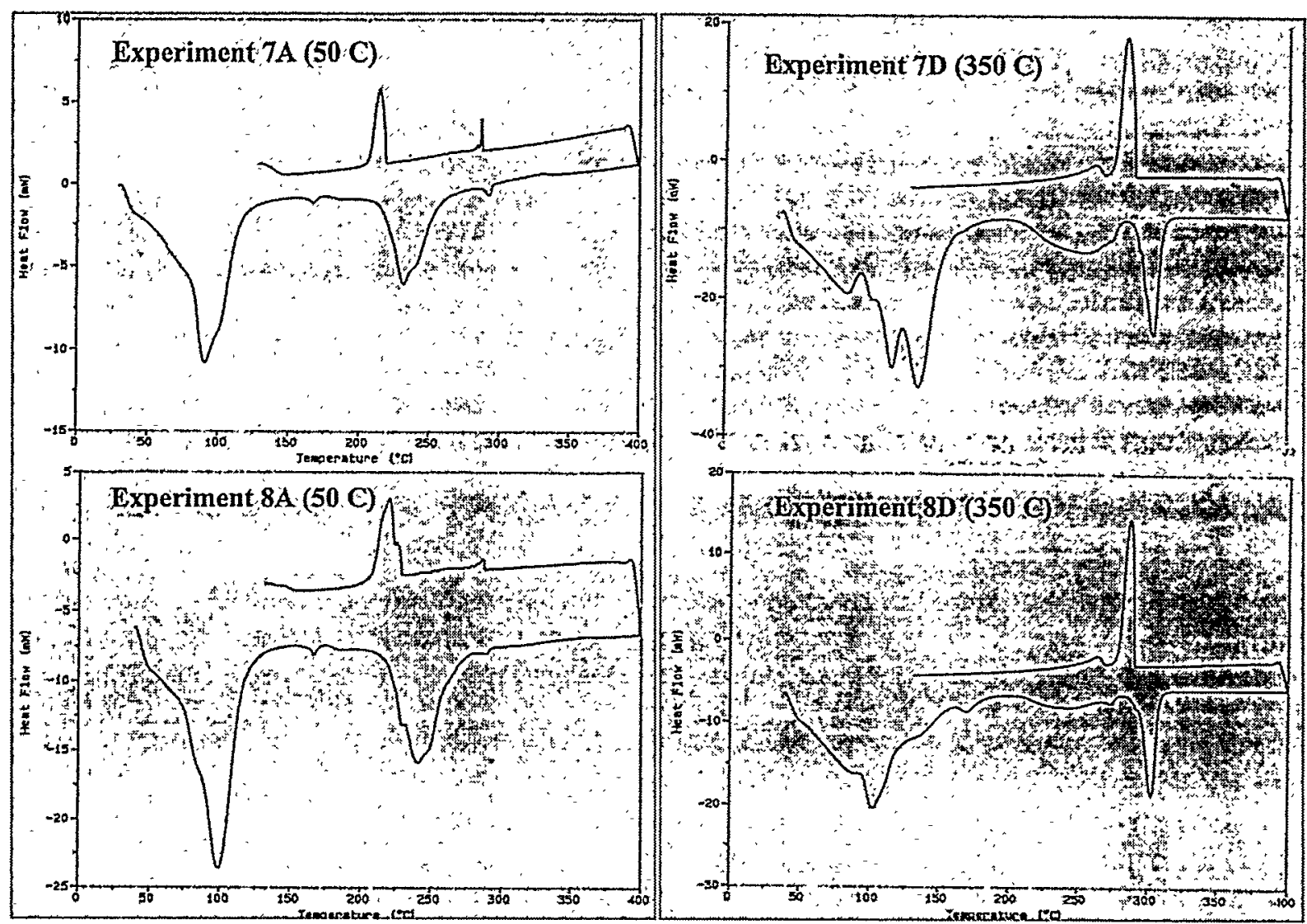

Figure 8. Combined influence of organic compounds and temperature on calorimetry measurements for simulated sludge.

In contrast, Series 8 samples - see Figure 8--contained mercury and silver at conservatively high concentrations. These measurements did not differ significantly from those of Series 7. Hence, the presence of the organic compounds studied does not appear to increase the potential for formation of energetic compounds during drying.

Hence, the sludge samples synthesized in this study showed no evidence of formation of energetic compounds even in the presence of high quantities of several organic compounds. Despite the addition of conservatively large amounts of mercury or silver, no samples suggested an explosive or exothermic behavior.

\section{Simulated Sludge Combined with Energetic Standards: DSC}

One can not exclude the possibility that negative results in tests with simulated sludge simply reflect non-representative synthesis of the samples. Hence, the program also investigated 
WSRC-TR-98-00407

Page 18 of 31

November 2, 1998

behavior of the simulated sludge after adding either mercury oxalate or mercury fulminate. This approach provided a means of characterizing the potential behavior of sludge and shock sensitive compound mixtures. These studies attempted to determine what concentrations of energetic compounds exhibited exothermic behavior, whether selected energetic compounds remained chemically stable in the sludge matrix, and if the presence of organic species in the mixtures propagated or increased the exothermic behavior of the mixtures.

Both mercury oxalate and mercury fulminate exist as shock sensitive compounds with sufficient stability to use as standards for such testing. Figure 9 and Figure 10 shows that the synthesized standards contained negligible impurities. Pure mercury oxalate and mercury fulminate, as prepared, decompose exothermically in air $(145 \mathrm{~J} / \mathrm{g}$ and $182 \mathrm{~J} / \mathrm{g}$, respectively) at temperatures of 225 and $167^{\circ} \mathrm{C}$, respectively (see Figure 11). Testing added each standard material to simulated sludge samples (see Appendix 1). Experiments added mercury oxalate and mercury fulminate into oven dried $\left(50^{\circ} \mathrm{C}\right)$ simulated sludge (Test Series 11 and 12, respectively), wet simulated sludge slurry (Test Series 13 and 14, respectively), and oven dried $\left(50^{\circ} \mathrm{C}\right)$ simulated sludge that contained a mixture of organic compounds (Test Series 15 and 16, respectively). Experiments used two or three concentrations of the specific energetic standard designated as either $U$ (i.e., ultra low: $1-2.5 \mathrm{wt} \%$ ), L (i.e., low: $4.9-9.3 \mathrm{wt} \%$ ), or $\mathrm{H}$ (i.e., high: $13.6-21.5 \mathrm{wt} \%$ ) to describe the concentration of the added standard. For example, Experiment $12 \mathrm{H}$ refers to a predried simulated sludge containing a mercury fulminate concentration of $21.5 \mathrm{wt} \%$.

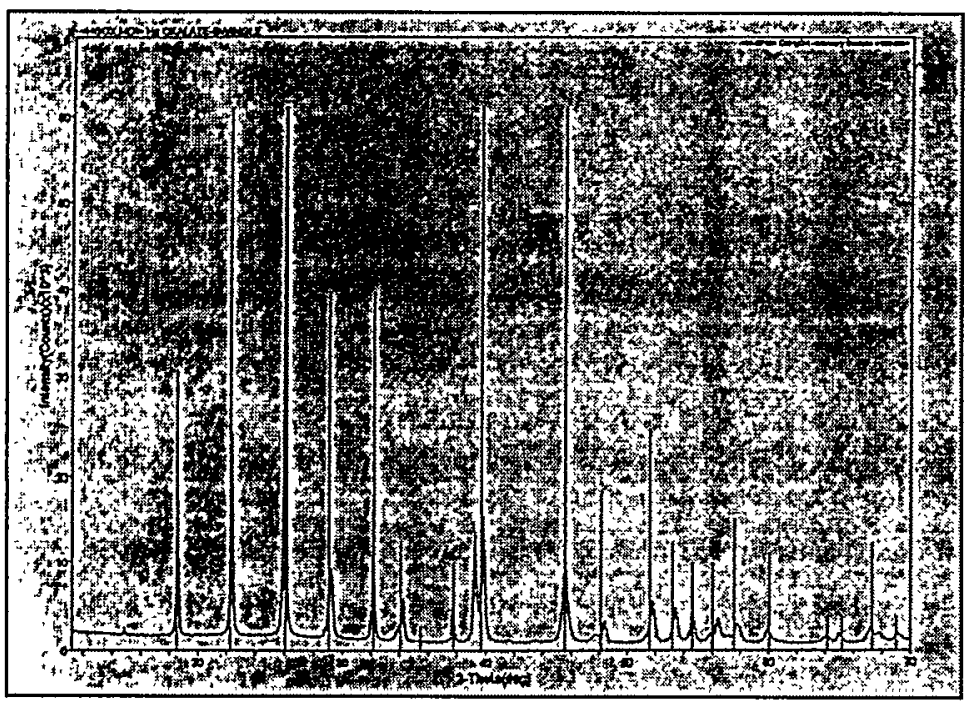

Figure 9. Diffraction patterns for pure mercury oxalate. 
WSRC-TR-98-00407

Page 19 of 31

November 2, 1998

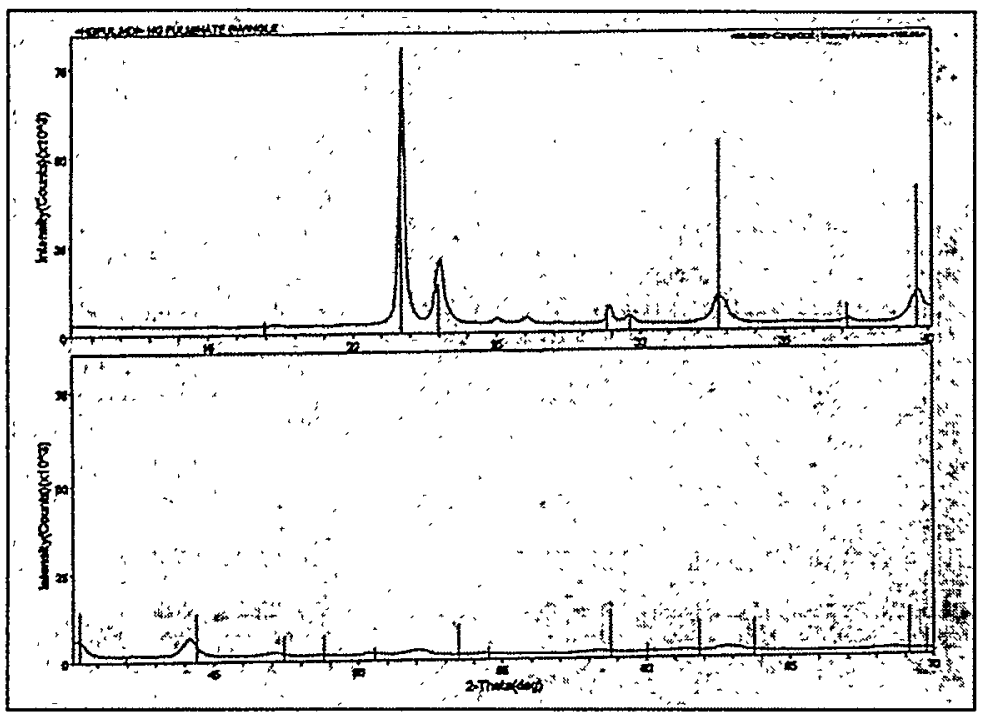

Figure 10. Diffraction patterns for pure mercury fulminate.

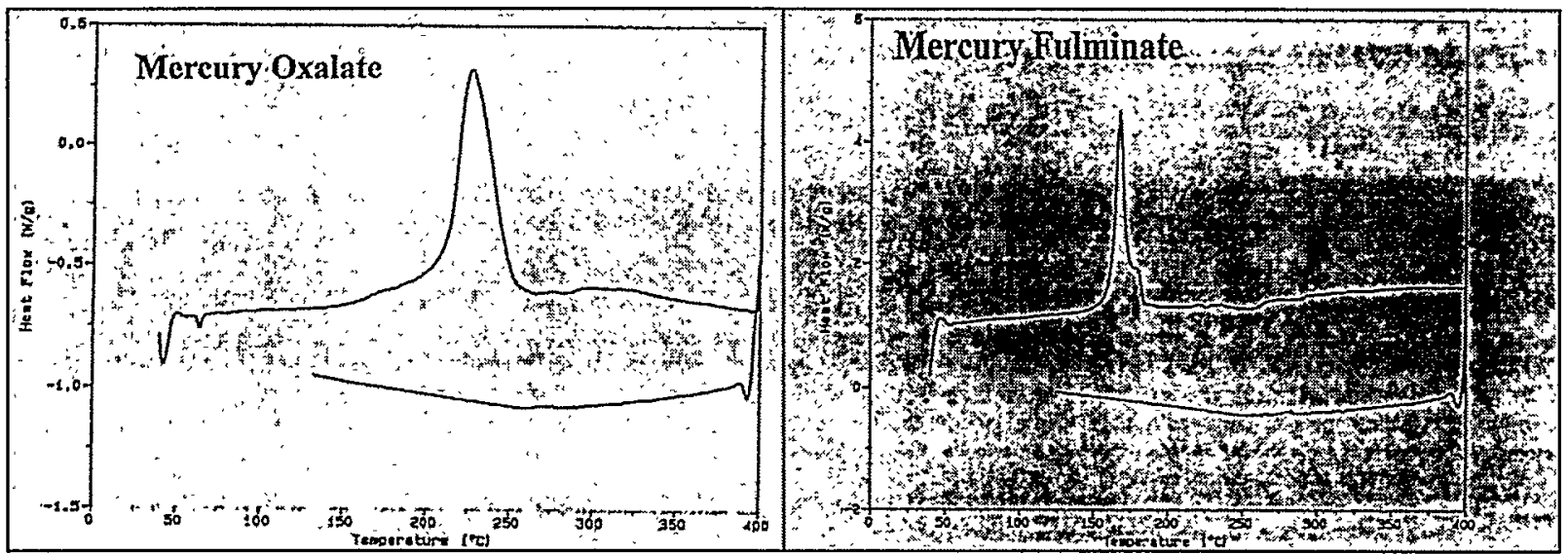

Figure 11. Calorimetry measurements for energetic standards.

Personnel subjected the prepared mixtures to both impact testing and DSC analysis. Test Series 11,13 , and 15 contained mercury oxalate. Figure 12 shows the DSC results for Experiments 11L and $11 \mathrm{H}$. Recall pure mercury oxalate decomposes thermally at $225^{\circ} \mathrm{C}$. The DSC spectra for Experiments $11 \mathrm{~L}$ and $11 \mathrm{H}$, when compared with the DSC for the baseline simulated sludge as shown in Figure 7 (Experiment 1A), indicate that an exothermic reaction occurs at $\sim 225^{\circ} \mathrm{C}$. The DSC spectra show that this exothermic reaction occurs in the midst of an endothermic reaction exhibited by the plain sludge. In other words, even though the energetic standard decomposes and gives off heat, the surrounding sludge absorbs the heat in a phase change reaction (most probably an aluminum oxide transition $\left.{ }^{16}\right)$. The net energy behavior remains endothermic at the concentrations tested.

Experiments $13 \mathrm{~L}$ and $13 \mathrm{H}$, while similar in composition, differ from Experiments $11 \mathrm{~L}$ and $11 \mathrm{H}$ since they use wet alkaline sludge during preparation and not pre-dried sludge. Exposure of mercury oxalate to alkaline solutions reportedly destroys the energetic compound. Examination of Figure 13 shows that mercury oxalate still present in the sludge mixtures after 1 day contact (i.e., the wet slurries containing the mercury oxalate dried overnight). Numerical analysis of the 
DSC spectra provides further insight. The energies detected for decomposition of either mercury oxalate or mercury fulminate correlated linearly with the mass of added material. The calculated energies for these experiments (Table 6) indicate that the degree of exothermic behavior at 225 ${ }^{\circ} \mathrm{C}$ nearly matches that predicted for the amount of added mercury oxalate.

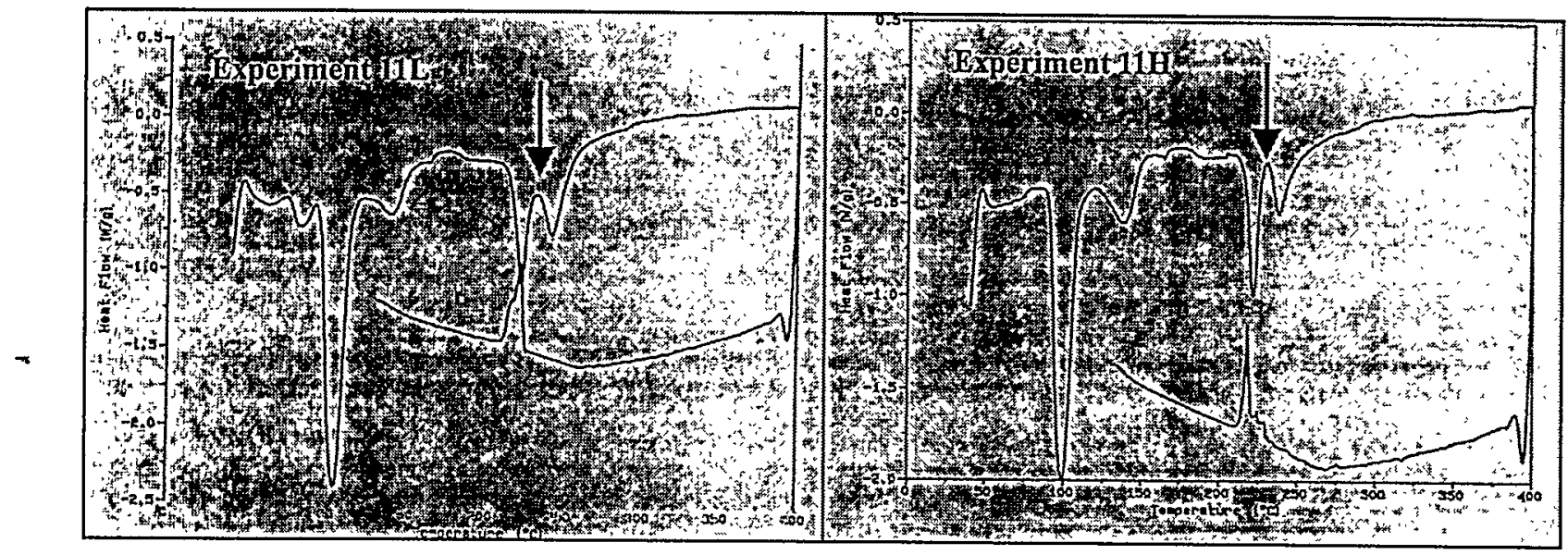

Figure 12. Calorimetry measurements of dry mercury oxalate added to dry sludge. (Arrows indicate location of exothermic peak for mercury oxalate.)

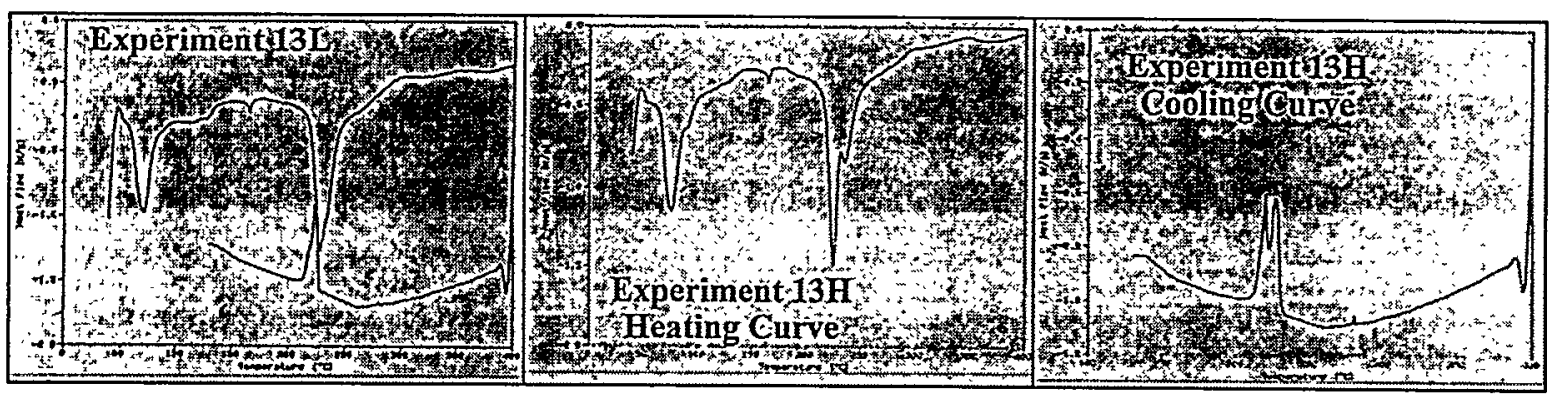

Figure 13. Calorimetry measurements of dry mercury oxalate added to wet sludge.

Sludge preparation for Experiments $15 \mathrm{U}, 15 \mathrm{~L}$, and $15 \mathrm{H}$ matched that of Experiments $11 \mathrm{~L}$ and $11 \mathrm{H}$ except the simulated sludge matrix contained organic compounds (total of 3 wt \%). Differential Scanning calorimetry results (shown in Figure 14) for $15 \mathrm{~L}$ and $15 \mathrm{H}$ appear very similar to that observed in Experiments 11L and 11H (see Figure 12). Therefore, the presence of organic compounds in the sludge matrix does not increase the exothermic behavior of the material. 
WSRC-TR-98-00407

Page 21 of 31

November 2, 1998

Table 6. Weight percent of explosives in simulated sludge mixtures.

\begin{tabular}{|c|c|c|c|}
\hline Experiment \# & Mixture & wt \% (added) & wt \% (DSC analysis) \\
\hline IIL & Dry sludge + oxalate & 5.99 & 6.2 \\
\hline $11 \mathrm{H}$ & Dry sludge + oxalate & 14.9 & 20 \\
\hline $12 \mathrm{U}$ & Dry sludge + fulminate & 2.20 & 3.9 \\
\hline $12 \mathrm{~L}$ & Dry sludge + fulminate & 9.30 & 9.53 \\
\hline $12 \mathrm{H}$ & Dry sludge + fulminate & 21.5 & 15.8 \\
\hline $13 \mathrm{~L}$ & Wet sludge + oxalate & 4.90 & 2.68 \\
\hline $13 \mathrm{H}$ & Wet sludge + oxalate & 13.6 & 14.9 \\
\hline $14 \mathrm{U}$ & Wet sludge + fulminate & 1.68 & 0 \\
\hline $14 \mathrm{~L}$ & Wet sludge + fulminate & 6.81 & 6.12 \\
\hline $14 \mathrm{H}$ & Wet sludge + fulminate & 17.5 & 17.0 \\
\hline $15 \mathrm{~L}$ & Dry + organic + oxalate & 5.98 & 5.9 \\
\hline $15 \mathrm{H}$ & Dry + organic + oxalate & 22.6 & 19.8 \\
\hline $16 \mathrm{U}$ & Dry + organic + fulminate & 2.32 & 0 \\
\hline $16 \mathrm{~L}$ & Dry + organic + fulminate & 8.75 & 6.4 \\
\hline $16 \mathrm{H}$ & Dry + organic + fulminate & 21.1 & 26.4 \\
\hline
\end{tabular}

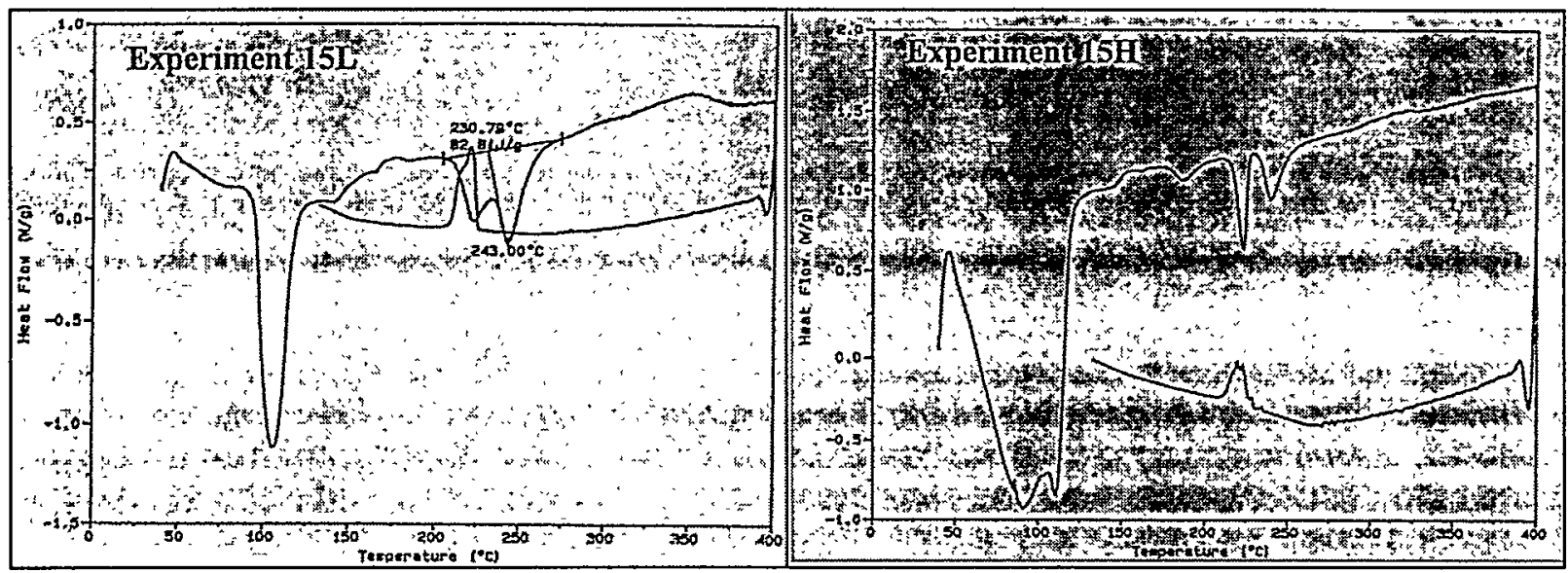

Figure 14. Calorimetry measurements of dry mercury oxalate added to dry sludge containing organic compounds.

Testing also examined the behavior of sludge with mercury fulminate added. Experiments 12U, $12 \mathrm{~L}$, and $12 \mathrm{H}$ examine the effects of mercury fulminate in pre-dried sludge (see Figure 15). Recall, mercury fulminate decomposes exothermically at $168{ }^{\circ} \mathrm{C}$. An exothermic reaction occurred in all three experiments at $\sim 168^{\circ} \mathrm{C}$. Furthermore, the energy released by the reaction increases with increasing concentration. However the level of energy released measured less than that needed to remove the water at low (i.e., $<100^{\circ} \mathrm{C}$ ) temperature. 
WSRC-TR-98-00407

Page 22 of 31

November 2, 1998
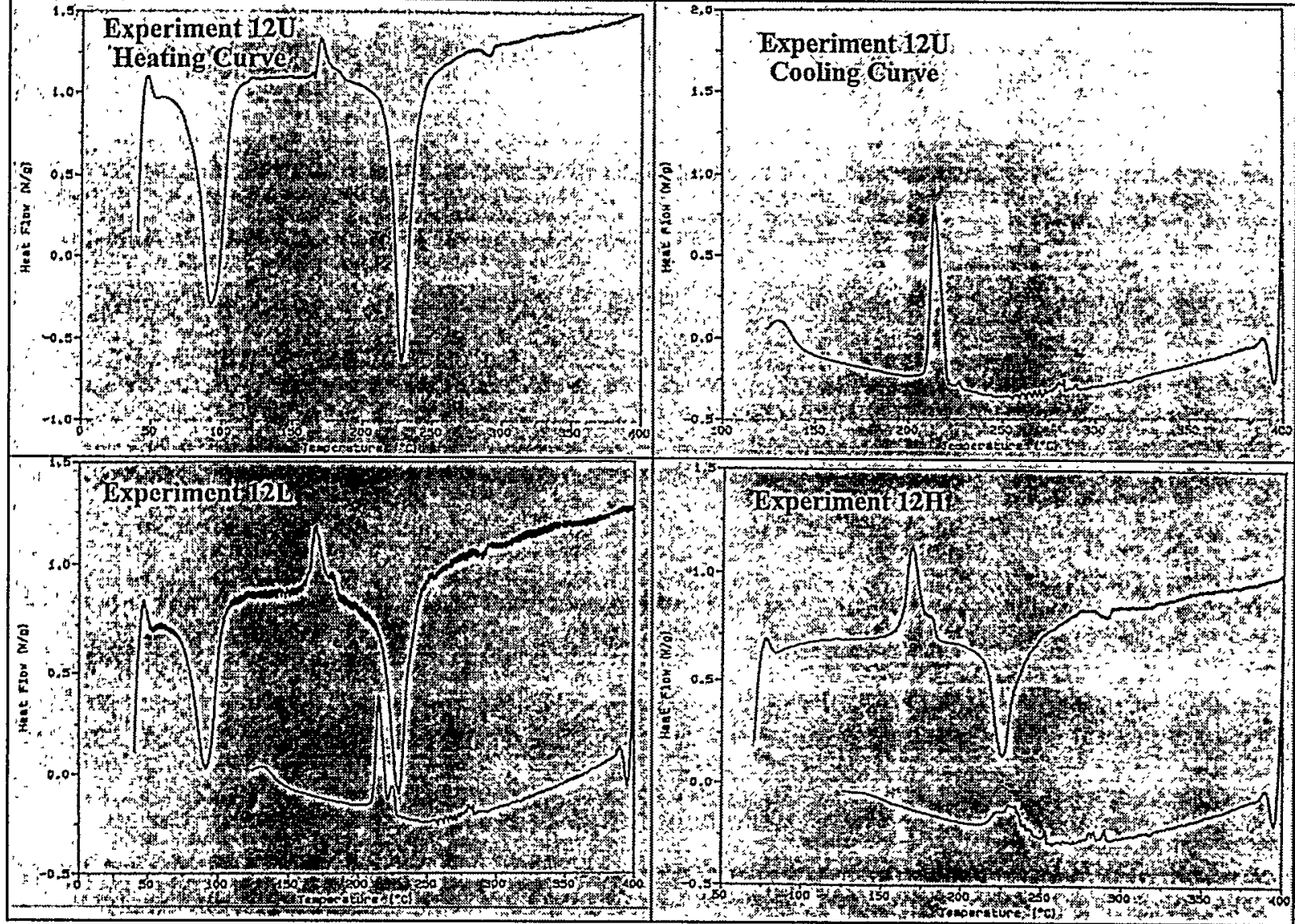

Figure 15. Calorimetry measurements of dry mercury fulminate added to dry sludge.

Experiments $14 \mathrm{U}, 14 \mathrm{~L}$, and $14 \mathrm{H}$ examine the influence of preparation using wet alkaline slurry. Again, literature suggests reaction of the fulminate with hydroxide will likely destroy the energetic material. Figure 16 exhibits the DSC results for the three experiments. Comparison of Figure 15 and Figure 16 indicates that the exothermic behavior remains essentially unchanged (given the slight difference in concentrations between the experimental sets). Numerical analysis of the data (Table 6) further confirms this visual observation. Therefore, short-term exposure (1 day) of mercury fulminate to slightly caustic solutions ( $0.22 \mathrm{M}$ hydroxide) does not destroy the energetic material.

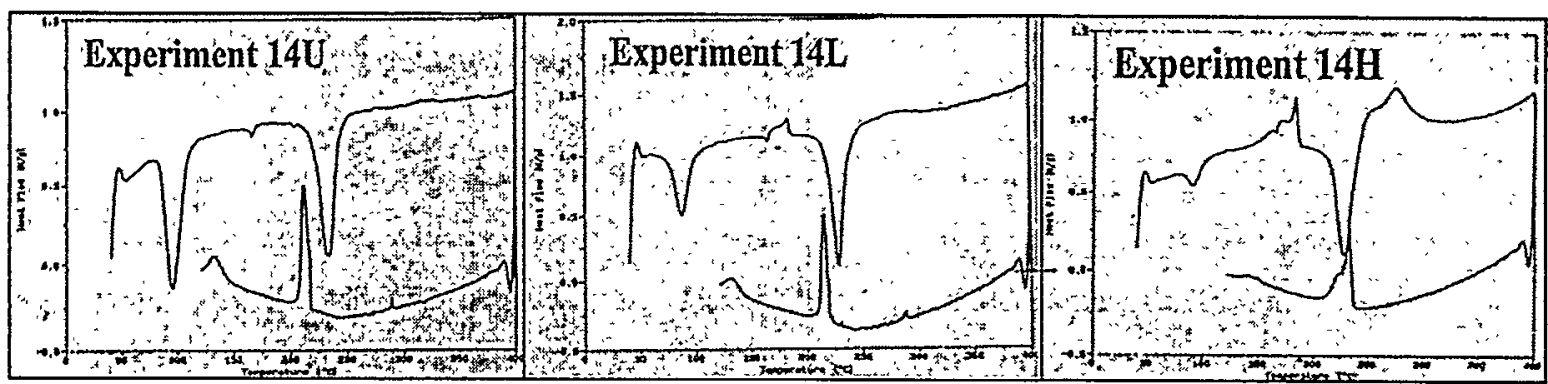

Figure 16. Calorimetry measurements of dry mercury fulminate added to wet sludge. 
WSRC-TR-98-00407

Page 23 of 31

November 2, 1998

Lastly, Experiments $16 \mathrm{U}, 16 \mathrm{~L}$, and $16 \mathrm{H}$ investigate the influence of organic compounds on the energetic behavior of the mixtures (see Figure 17). Comparison of Figure 17 with Figure 15 indicates the presence of organic compounds (at $3 \mathrm{wt} \%$ ) did not influence the exothermic behavior of the energetic material.

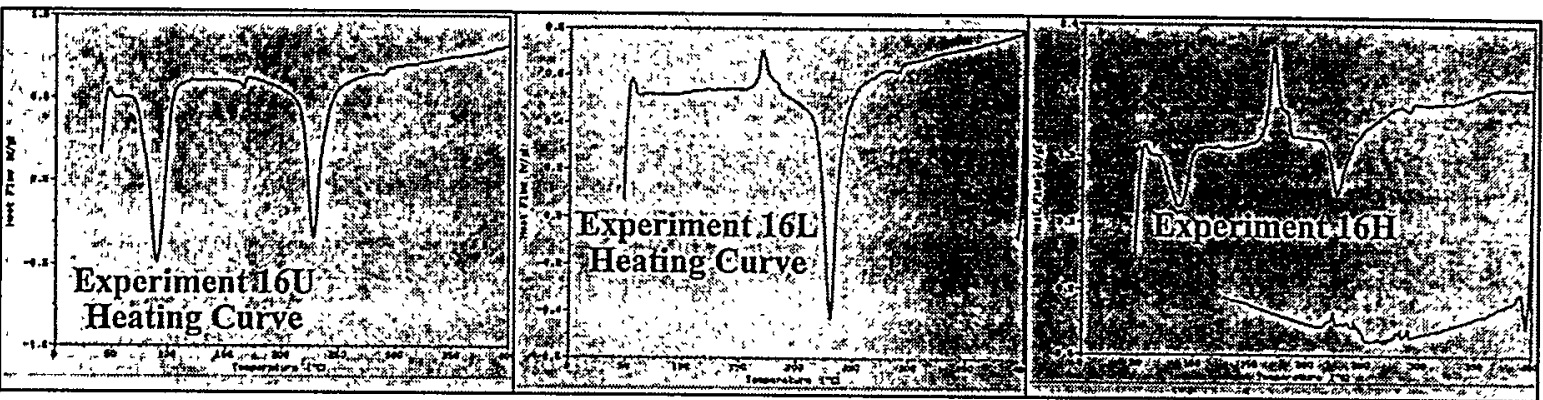

Figure 17. Calorimetry measurements of dry mercury fulminate added to dry sludge containing organic compounds.

\section{Synergetic Interactions with Energetic Standards: DSC}

The work described in the previous sections does not, however, fully investigate potential synergistic influences of energetic compounds with sludge and other components. For instance, one concern involves the potential for a limited amount of an energetic material to propagate a reaction into the larger amounts of organic compounds present. Alternatively, a small amount of a silver compound might cause the reaction of a mercury compound. Researchers conducted a few experiments to provide insight into these two scenarios.

Figure 18 examines the direct interaction of a mixture of mercury fulminate with a mixture of organic compounds (i.e., $30 \mathrm{vol} \%$ tri-n-butyl phosphate in paraffin, vendor supplied Ionac 604 resin, and permanganate digested Ionac 604 resin). The DSC shows evidence of direct combustion of the organic species in air as evidenced by the exothermic peaks centered near temperatures of $140,250,310$, and $375^{\circ} \mathrm{C}$ ). The limited masses of organic compounds added in the simulated sludge - at concentrations well exceeding that expected in the tank farm waste make observation of this behavior difficult in the presence of the sludge. Note the lack of a strong energetic peak near $167^{\circ} \mathrm{C}$ (e.g., see Figure 11) typical for fulminate. The visual observation and numerical analysis of the spectra indicate the organic compounds suppress the reaction of the fulminate. 
WSRC-TR-98-00407

\section{Page 24 of 31}

November 2, 1998

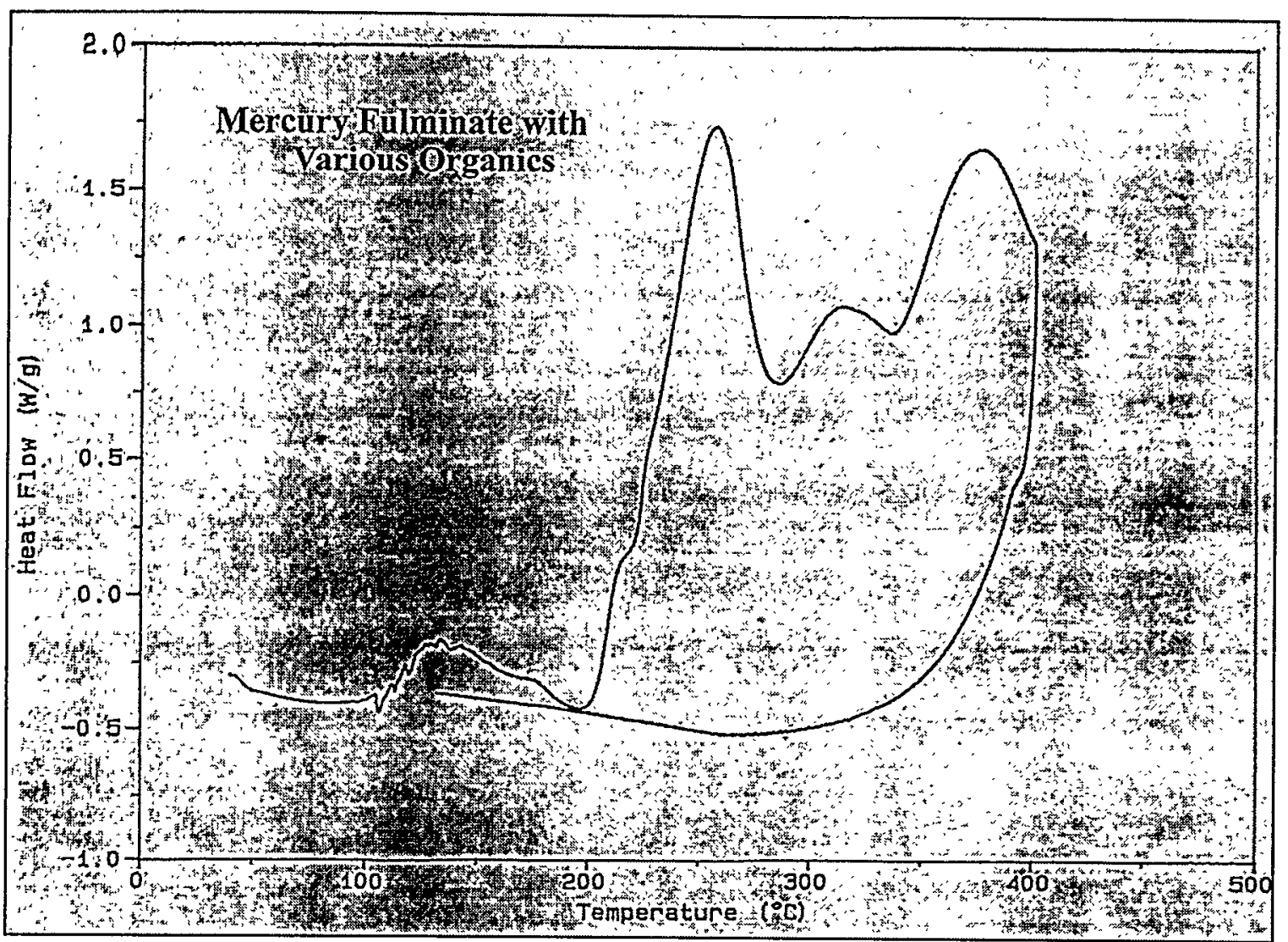

Figure 18. Calorimetry measurements for mixture of mercury fulminate with various organic compounds.

Figure 19 provides insight into the behavior that results for a nearly equal weight mixture of mercury oxalate and mercury fulminate. The exothermic reaction that occurs when the fulminate decomposes that also consumes the oxalate. Hence, mixtures of energetic compounds effectively lower the threshold amount needed to form a highly reactive mixture. The limited duration of this program did not allow investigation of whether coexistence of energetic compounds in sludge could result in significant exothermic behavior at relatively low concentrations. The study did not examine the behavior in combination with the simulated sludge. Presumably, sludge would dampen the potential for propagation of the reaction acting to disperse the energy from the initial exothermic reaction. The heat capacity, phase transition, and water content of the sludge would help dampen any interaction. However, testing did not verify this speculated behavior. 


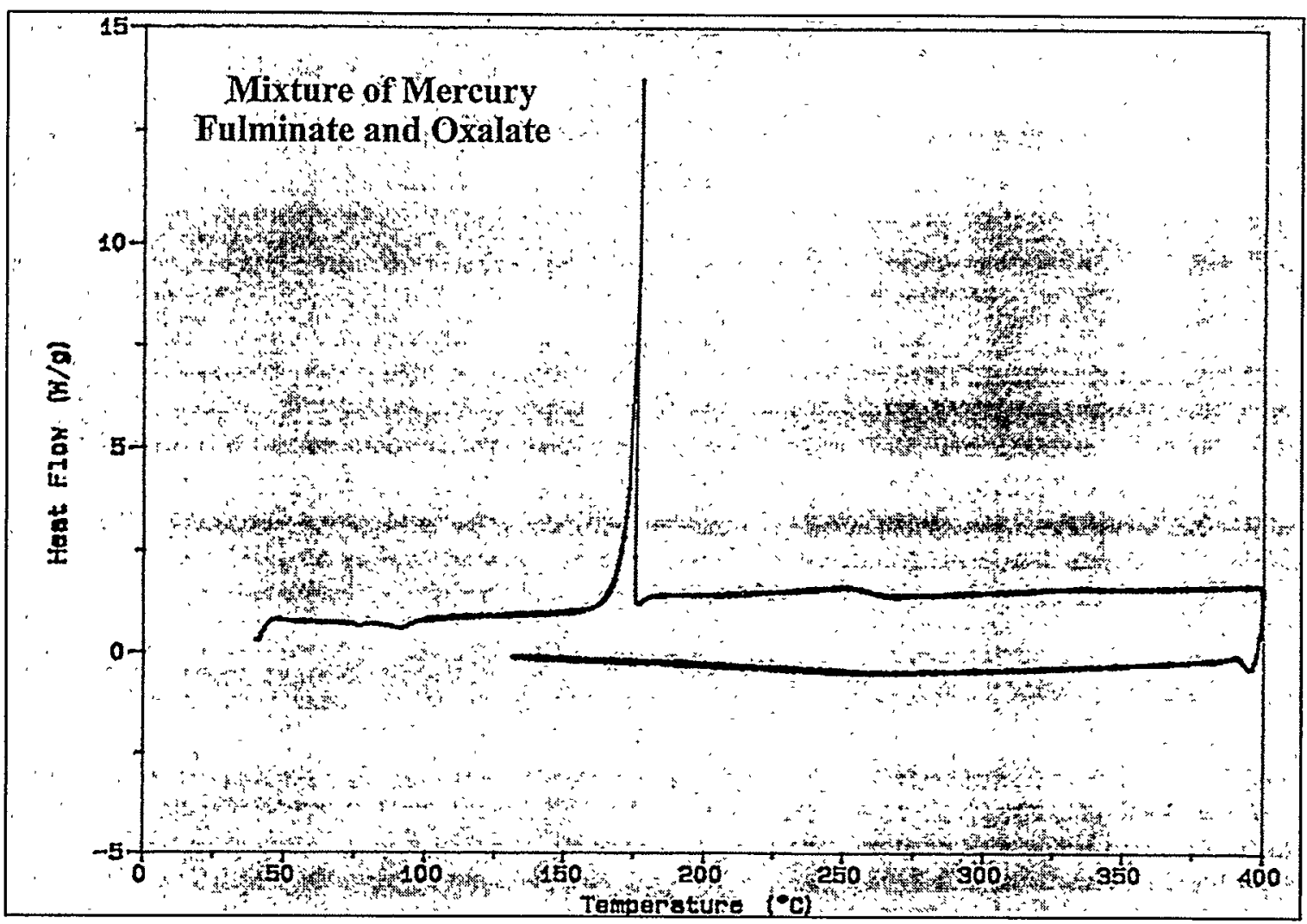

Figure 19. Calorimetry measurement for a mixture of mercury oxalate and mercury fulminate.

\section{CONCLUSIONS}

While the experimental data does not preclude the existence of energetic compound in dry sludge, the information does suggest that such compounds will not likely form in the alkaline conditions. If formed, literature and expert knowledge suggest compounds like mercury oxalate and mercury fulminate will exhibit limited lifetimes due to reaction in the caustic environment. (These tests used a mild concentration of caustic - i.e., $0.22 \mathrm{M}$ free hydroxide - and a short contact duration. At those limited conditions, the data show no evidence of decomposition.) Even with high concentrations of these compounds in sludge samples, the energy released during the sludge matrix dissipated the energy released during the reaction, so that the ASTM standard test did not provide positive indications of a reaction.

The composite data from these studies suggest that sampling of Tanks $12 \mathrm{H}$ and $15 \mathrm{H}$ with the impact device as currently designed ${ }^{17}$ poses a low level of risk. 


\section{Future Program Elements}

The results of the current work suggest several areas that merit further study.

- Future work should examine the expected lifetime of selected energetic compounds in caustic media. Testing should likely include at least mercury oxalate, mercury fulminate, and silver nitride.

- Conduct additional calorimetry studies examining the behavior of simulated sludge with mixtures of energetic compounds. In particular, investigate the influence of the combined presence of silver nitride and mercury oxalate.

- Conduct vendor testing at larger scale to confirm these results and to provide information relative to propagation of any reaction into the organic compounds present.

\section{QUALITY ASSURANCE}

Laboratory notebook WSRC-NB-96-667 (M. S. Hay, page 41) contains data from the characterization of samples from Tanks $8 \mathrm{~F}, 12 \mathrm{H}$, and $15 \mathrm{H}$. Notebook WSRC-NB-98-00161 (K. L. Prettel, page 5) contains the recent DSC data as well as information on the synthesis of the simulated sludge. Notebook WSRC-NB-98-0238 (R. F. Swingle, pages 5-73) contains data from the impact testing. Notebook WRC-NB-97-0064 (W. R. Wilmarth, pages 26-28) contains the information on the synthesis of the mercury oxalate and mercury standards as well as the training records for personnel.

\section{ACKNOWLEGEMENTS}

Kevin Kalbaugh repaired the equipment and performed the calorimetry measurements on the Tank $15 \mathrm{H}$ sample. Bill Walker provided the digested resin added to the simulated sludge samples.

\section{REFERENCES}

\footnotetext{
'D. T. Hobbs, "Possible Explosive Compounds in the Savannah River Site Waste Tank Farm Facilities (U)," WSRC-TR-91-444, Revision 1, April 27, 1995.

${ }^{2}$ R. H. Ross, "Evaluation of Tank 15H Archive Sludge and Tank 12H Core Sample for Shock Sensitive Compounds," HLE-TTE-98044, March 9, 1998.

${ }^{3}$ R. F. Swingle, "Task Technical and Quality Assurance Plan for Characterization of Dry Sludge," WSRC-RP-9800349 , Revision 0, June 18, 1998.

${ }^{4}$ D. T. Hobbs, "Recommended Standard Materials for Evaluation of Dry Sludge Energetic Reactions," WSRC-TR98-00262, August 19, 1998.

${ }^{5}$ C. J. Coleman, W. F. Kinard, N. E. Bibler, D. F. Bickford and W. G. Ramsey, "Determination of Nobel Metals in Savannah River Site High-Level Waste Sludge (U)," WSRC-MS-90-262, February 24, 1991.

6D. D. Walker, laboratory notebook, "Tank 15 Salt Solution," DPSTN-4385, page 10, September 12, 1983.

${ }^{7}$ Temperature from monthly report of facility, DPSP-64-1-11-S, November, 1964.

${ }^{8} \mathrm{~J}$. R. Fowler, "Sludge Composition for each Tank and DWPF Feed Batches," DPST-84-556, June 11, 1984.

9 ASTM E680-79, "Standard Test Method for Drop Weight Impact Sensitivity of Solid-Phase HazardôsTMaterials," re-approved 1992.
} 
WSRC-TR-98-00407

Page 27 of 31

November 2, 1998

${ }^{10} \mathrm{M}$. W. Geeting, "Use of Impact Tester on Shock Sensitive Standards and Samples," Manual L12.1, Instruction IWPT-001, Revision 0, September 2, 1998.

"H. H. Cady, "Evaluation of:Ferrocynide/Nitrate Explosive Hazard," LA-12589-MS, June 1992.

${ }^{12}$ W. R. Wilmarth, "Mercury Fulminate and Mercury Oxalate Synthesis and Associated Sludge Testing," Manual L12.1, Instruction I-WPT-001, Revision 0, September 2, 1998.

${ }_{13}^{13}$ R. Meyer, EXPLOSIVES, $2^{\text {nd }}$. Ed., Verlag Chemie, 1981, Deerfield Beach, FL.

${ }^{14}$ R. M. Wallace, "Explosion Hazard of Mercury and Silver Oxalates During Cleaning of Tank 16H", DPST-77517, December 19, 1977.

${ }_{15}$ L. Bretherick, HANDBOOK OF REACTIVE CHEMICAL HAZARDS, 3rd. Ed., Butterworths, 1985, London. 16 "14. Oxides and Hydroxides" (pages 1032-1034), "14.1 Aluminum Trihydroxide, Al(OH)" (pages (1034-1035), and "14.2 Aluminum Oxide Hydroxide, AlO(OH)" (page 1035), in COMPREHENSIVE INORGANIC

CHEMISTRY, Volume 1, First edition, J. C. Bailar et al., editors, Pergamon Press, New York, 1973.

${ }_{17}$ T. A. Nance, Design Drawing: "Tank 12 Dry Sludge Sampling Device," R-R1-F-0051, Rev. 0, November 9, 1998. 
WSRC-RP-98-00349

Page 28 of 3

Revision 0

June 18, 1998

\section{APPENDIX 1}

The following tables provide more detailed information regarding the experimental conditions and composition of materials.

Table 7. Simulated sludge experimental design.

\begin{tabular}{|c|c|c|c|c|c|c|c|c|}
\hline \multirow{2}{*}{ Additive } & \multicolumn{9}{|c|}{ Simulant ID } \\
\cline { 2 - 9 } & $\mathbf{1}$ & $\mathbf{2}$ & $\mathbf{3}$ & $\mathbf{4}$ & $\mathbf{5}$ & $\mathbf{6}$ & $\mathbf{7}$ & $\mathbf{8}$ \\
\hline Mercury & -1 & 1 & -1 & -1 & -1 & -1 & -1 & 1 \\
\hline Silver & -1 & 1 & -1 & -1 & -1 & -1 & -1 & 1 \\
\hline Ionac 604 (undigested) & -1 & -1 & 1 & -1 & -1 & -1 & 0 & 0 \\
\hline Ionac 604 (digested) & -1 & -1 & -1 & 1 & -1 & -1 & 0 & 0 \\
\hline $\begin{array}{c}\text { tri-n-butyl phosphate/ } \\
\text { n-paraffin (30/70 vol \%) }\end{array}$ & -1 & -1 & -1 & -1 & 1 & -1 & 0 & 0 \\
\hline Sodium oxalate & -1 & -1 & -1 & -1 & -1 & 1 & 0 & 0 \\
\hline Temperature* & & & & & & & & \\
\hline
\end{tabular}

${ }^{*} \mathrm{~A}=50^{\circ} \mathrm{C}, \mathrm{B}=150^{\circ} \mathrm{C}, \mathrm{C}=250^{\circ} \mathrm{C}, \mathrm{D}=350^{\circ} \mathrm{C}$

Table 8. Simulated sludge experimental design concentrations.

\begin{tabular}{|c|c|c|c|}
\hline \multirow{2}{*}{ Additive } & \multicolumn{3}{|c|}{ Concentration (wt \%) } \\
\cline { 2 - 4 } & -1 & 0 & 1 \\
\hline Mercury & 0 & NA & 6 \\
\hline silver nitrate & 0 & NA $^{\mathrm{a}}$ & 0.0015 \\
\hline Ionac 604 (undigested) & 0 & 0.75 & 3 \\
\hline lonac 604 (digested) & 0 & 0.75 & 3 \\
\hline $\begin{array}{c}\text { tri-n-butyl phosphate/ } \\
\text { n-paraffin } \\
\text { (30/70 vol \%) }\end{array}$ & 0 & 0.75 & 3 \\
\hline Sodium oxalate & 0 & & 3 \\
\hline
\end{tabular}

NA indicates level not tested. 
WSRC-TR-98-00407

Page 29 of 31

November 2, 1998

Table 9. Experimental design of mercury oxalate and fulminate bearing simulated sludge compositions.

\begin{tabular}{|c|c|c|c|c|c|c|c|c|}
\hline \multirow[b]{2}{*}{ Additive } & \multicolumn{8}{|c|}{ Simulant ID } \\
\hline & 9 & 10 & $11 \mathrm{~L}-\mathrm{H}^{\mathrm{a}}$ & $12 \mathrm{U}-\mathrm{H}^{2}$ & $13 \mathrm{~L}-\mathrm{H}^{2}$ & $14 \mathrm{U}-\mathrm{H}^{2}$ & $150-H^{a}$ & $16 \mathrm{U}-\mathrm{H}^{\mathrm{a}}$ \\
\hline Mercury oxalate & 1 & -1 & $T$ & -1 & $T$ & -1 & $T$ & -1 \\
\hline Mercury fulminate & -1 & 1 & -1 & I & -1 & 1 & -1 & 1 \\
\hline Inoac A641 (undigested) & -1 & -1 & -1 & -1 & -1 & -1 & 0 & 0 \\
\hline Inoac A641 (digested) & -1 & -1 & -1 & -1 & -1 & -1 & 0 & 0 \\
\hline Tri-n-butylphosphate & -1 & -1 & -1 & -1 & -1 & -1 & 0 & 0 \\
\hline n-parrafin & -1 & -1 & -1 & -1 & -1 & -1 & 0 & $\sigma$ \\
\hline Sodium oxalate & -1 & -1 & -1 & -1 & -1 & -1 & 0 & 0 \\
\hline emperature/Condition & ure & ure & $50^{\circ} \mathrm{C}^{\mathrm{c}}$ & $\sigma^{\circ} \mathrm{C}^{\mathrm{C}}$ & $50^{\circ} \mathrm{C}^{4}$ & $50^{\circ} \mathrm{C}^{4}$ & $50^{\circ} \mathrm{C}^{\circ}$ & $50^{\circ} \mathrm{C}$ \\
\hline
\end{tabular}
added to the simulant where $\mathrm{U}=$ ultralow, $\mathrm{L}=$ low, and $\mathrm{H}=$ high.

'Mercury oxalate and fulminate tested as pure components (i.e., not blended with sludge).

"Mercury oxalate and fulminate mixed with simulated sludge previously dried at $50{ }^{\circ} \mathrm{C}$ (dried sludge simulant $1 \mathrm{~A}$ ).

${ }^{d}$ Mercury oxalate and fulminate mixed with simulated sludge slurry and then dried at $50{ }^{\circ} \mathrm{C}$ (wet sludge simulant 1A).

"Mercury oxalate and fulminate mixed with organic-bearing simulated sludge previously dried at $50^{\circ} \mathrm{C}$ (dried sludge simulant 7A).

Table 10. Experimental concentrations of mercury oxalate and fulminate in simulated sludge compositions.

\begin{tabular}{|c|c|c|}
\hline \multirow{2}{*}{ Simulant ID } & \multicolumn{2}{|c|}{ Concentration (wt \%) } \\
\cline { 2 - 3 } & Mercury Oxalate & Mercury Fulminate \\
\hline 9 & pure & NA $^{\mathrm{a}}$ \\
\hline 10 & $\mathrm{NA}$ & Pure \\
\hline $11 \mathrm{~L}$ & 5.99 & $\mathrm{NA}$ \\
\hline $1 \mathrm{H}$ & 14.9 & $\mathrm{NA}$ \\
\hline $12 \mathrm{U}$ & $\mathrm{NA}$ & 2.20 \\
\hline $12 \mathrm{~L}$ & $\mathrm{NA}$ & 9.30 \\
\hline $12 \mathrm{H}$ & $\mathrm{NA}$ & 21.5 \\
\hline $13 \mathrm{~L}$ & 4.90 & $\mathrm{NA}$ \\
\hline $13 \mathrm{H}$ & 13.6 & $\mathrm{NA}$ \\
\hline $14 \mathrm{U}$ & $\mathrm{NA}$ & 1.68 \\
\hline $14 \mathrm{~L}$ & $\mathrm{NA}$ & 6.81 \\
\hline $14 \mathrm{H}$ & $\mathrm{NA}$ & 17.5 \\
\hline $15 \mathrm{U}$ & 1.58 & $\mathrm{NA}$ \\
\hline $15 \mathrm{~L}$ & 5.98 & $\mathrm{NA}$ \\
\hline $15 \mathrm{H}$ & $14.9\left(2^{\text {nd batch } 22.6)}\right.$ & $\mathrm{NA}$ \\
\hline $16 \mathrm{U}$ & $\mathrm{NA}$ & 2.32 \\
\hline $16 \mathrm{~L}$ & $\mathrm{NA}$ & 8.75 \\
\hline $16 \mathrm{H}$ & $\mathrm{NA}$ & 21.1 \\
\hline
\end{tabular}


WSRC-TR-98-00407

Page 30 of 31

November 2, 1998

Table 11. Listing of impact tests.

\begin{tabular}{|c|c|c|}
\hline Sludge Sample Tested & Number of Impact Tests & Results \\
\hline 9 (Pure Mercury Oxalate) & 23 & $\begin{array}{c}\text { Minimum Level of } \\
\text { Detection by Smoke }-3 \mathrm{mg} \\
\text { total mercury oxalate }\end{array}$ \\
\hline$\frac{1-A}{7-1}$ & 6 & No reaction detected \\
\hline$\frac{7-1}{0-1}$ & 5 & No reaction detected \\
\hline 8-A & 6 & No reaction detected \\
\hline$\Pi 1-L$ & 5 & No reaction detected \\
\hline $11-\mathrm{H}$ & $5\left(4^{*}\right)$ & No reaction detected \\
\hline 13-L & 5 & No reaction detected \\
\hline 13-H & 5 & No reaction detected \\
\hline 15-L & 5 & No reaction detected \\
\hline $15-\mathrm{H}$ & $5\left(3^{*}\right)$ & No reaction detected \\
\hline $\begin{array}{l}\text { 10 (Pure Mercury } \\
\text { Fulminate) }\end{array}$ & 16 & $\begin{array}{l}\text { Minimum Level of } \\
\text { Detection by Smoke }-2 \mathrm{mg} \\
\text { total mercury fulminate; } \\
\text { sparks observed in } 3 \text { tests }\end{array}$ \\
\hline $11-0$ & 2 & No reaction detected \\
\hline $2-\mathrm{A}$ & 2 & No reaction detected \\
\hline $12-0$ & 6 & No reaction detected \\
\hline $12-L$ & $6\left(4^{*}\right)$ & No reaction detected \\
\hline $12-\mathrm{H}^{2}$ & $6\left(6^{*}\right)$ & No reaction detected \\
\hline $16-U$ & 6 & No reaction detected \\
\hline 16-L & $6\left(3^{*}\right)$ & No reaction detected \\
\hline $16-\mathrm{H}$ & $6\left(6^{*}\right)$ & No reaction detected \\
\hline $14-0$ & 7 & No reaction detected \\
\hline $14-\mathrm{L}$ & 6 & No reaction detected \\
\hline $14-\mathrm{H}$ & $6\left(6^{*}\right)$ & No reaction detected \\
\hline
\end{tabular}

andere mercury oxalate or fulminate least $15 \mathrm{wt} \%$ of either fulminate or oxalate. 
WSRC-TR-98-00407

Page 31 of 31

November 2, 1998

\section{DISTRIBUTION}

S. M. Aleman, 703-H

M. J. Barnes, 773-A

T. E. Britt, 703-H

N. R. Davis, 703-H

V. G. Dickert, 703-H

L. 0. Dworjanyn, 779-2A

S. D. Fink, 773-A

F. F. Fondeur, 773-62A

M. W. Geeting, 773-24A

M. S. Hay, 773-A

D. T. Hobbs, 773-A

G. J. Hutchens, 703-H

- M. D. Johnson, 703-H

B. L. Lewis, 703-H

T. J. Lex, 703-H

P. E. Lowe, 773-41A

T. M. Monahan, 703-H

J. P. Morin, 703-H

T. A. Nance, 723-A

L. M. Nelson, 773-43A

L. M. Papouchado, 773-A

R. H. Ross, 703-H

M. S. Shurrab, 703-H

W. L. Tamosaitis, 773-A

T. C. Temple, 703-H

W. B. Van-Pelt, 679-T

D. D. Walker, 773-A

W. R. Wilmarth, 773-42A

TIM, 703-43A

WPTS Files, c/o C. C. Canada, 773-A 